\title{
TREMA DOMINGENSIS RISES LIKE A PHOENIX FROM THE ASHES OF TREMA INTEGERRIMA: A REASSESSMENT OF THE ENTIRE-LEAVED SPECIES \\ OF NEOTROPICAL TREMA (CANNABACEAE) \\ ${ }^{1}$ Nancy C. Garwood, ${ }^{2}$ Kristina Jordan, ${ }^{3}$ Nicholas D. Flowers
}

Department of Plant Biology

Southern Illinois University

Carbondale, Illinois 62901, U.S.A.

ngarwood@plant.siu.edu, kljordan95@gmail.com,nickflowers@siu.edu

\author{
${ }^{4}$ Aelys M. Humphreys \\ Department of Ecology, Environment and Plant Sciences \\ Stockholm University \\ Stockholm 106 91, SWEDEN \\ aelys.humphreys@su.se
}

${ }^{5}$ Stephen J. Russell

Core Research Laboratories
Natural History Museum
London SW75BD, UK
s.russell@nhm.ac.uk

\author{
${ }^{6}$ Kurt M. Neubig* \\ Department of Plant Biology \\ Southern Illinois University \\ Carbondale, Illinois 62901, U.S.A. \\ kneubig@siu.edu \\ *Corresponding author
}

\section{ABSTRACT}

We resolve three problems concerning the three entire-leaved species of Neotropical Trema. 1) Phylogenetic and morphological results showed that T. integerrima (Beurl.) Standl., T. domingensis Urb., and T. laxiflora Lundell are a single species; therefore, we combine them under a single name. 2) The date of publication gives priority to T. integerrima, as the basionym Sponia integerrima Beurl. was published in 1856. However, the type specimen, Billberg 308 (S), is not a species of Trema but Pouzolzia obliqua (Wedd.) Wedd. (Urticaceae); therefore, Sponia integerrima Beurl. is a new synonym of $P$. obliqua. The next available name for the entire-leaved species is T. domingensis, published in 1912. 3) The type of T. domingensis, Fuertes 312, is a mixed collection. Specimens of Fuertes 312 held at B, NY, U, and USD are T. domingensis, while those at $\mathrm{P}, \mathrm{G}, \mathrm{US}$, and $\mathrm{Z}$ are Celtis trinervia Lam. We provide a historical review to understand how these problems arose and persisted unnoticed for decades.

\section{RESUMEN}

Resolvimos tres problemas concernientes a las tres especies neotropicales de hojas enteras de Trema. 1) Los resultados filogenéticos y morfológicos mostraron que T. integerrima (Beurl.) Standl., T. domingensis Urb. y T. laxiflora Lundell son una sola especie; así que las combinamos a un solo nombre. 2) La fecha de publicación da prioridad a T. integerrima, ya que el basiónimo Sponia integerrima Beurl se publicó en 1856. Sin embargo, el espécimen tipo Billberg 308 (S) no es una especie de Trema sino Pouzolzia obliqua (Wedd.) Wedd. (Urticaceae); por lo tanto, Sponia integerrima Beurl. es un nuevo sinónimo de P. obliqua. El siguiente nombre disponible para esta especie era T. domingensis, publicado en 1912. 3) El tipo de T. domingensis era una colección mixta. Los especímenes de Fuertes 312 almacenados en B, NY, Y y USD son T. domingensis, mientras que los de P, G, US y Z son Celtis trinervia Lam. Proporcionamos una reseña histórica para comprender cómo surgieron estos problemas y persistieron desapercibidos durante décadas.

KeY WoRds: Cannabaceae, leaf morphometrics, Neotropics, phylogeny, pioneer tree, Sponia integerrima, taxonomic history, Trema domingensis, Trema integerrima, Trema laxiflora, trichomes

\section{INTRODUCTION}

We are re-examining types of all New World Trema species as part of a phylogenetic study and taxonomic revision of New World Trema (Cannabaceae). Earlier we revised the lectotype of Rhamnus micranthus L., the basionym of T. micrantha (L.) Blume, the most widespread and complex Neotropical taxon (Garwood 2016). Here we focus on the three entire-leaved species of Trema, which are found only in the New World: T. domingensis 
Urb., T. integerrima (Beurl.) Standl., and T. laxiflora Lundell. Standley (1933) introduced the new combination Trema integerrima, based on Beurling's (1854 [1856]) Sponia integerrima from Panama. Urban (1912) described Trema domingensis (as domingense) based on a single collection from the Dominican Republic. Lundell (1960) described Trema laxiflora from two of his own collections from Guatemala. While all three have been afforded species status (Ulloa Ulloa et al. 2017), T. laxiflora has also been considered a synonym of T. integerrima (e.g., Nee 2015; Tropicos 2018c). The relationship of mainland T. integerrima and T. laxiflora to the Caribbean T. domingensis has never been evaluated. Of the three species, T. integerrima is the most abundant and widespread, known from Belize to Bolivia (Todzia 2001; Nee 2015; Tropicos 2018b), and is now widely represented in herbaria (e.g., 217 records in GBIF 2017a). In contrast, T. domingensis is thought to be endemic to and possibly extinct in the Dominican Republic (Zanoni \& Mejía 1989; Liogier 1996; García et al. 2001; AcevedoRodríguez \& Strong 2012; Tropicos 2018d) and T. laxiflora is known only from Guatemala and Mexico (Lundell 1960; Grandtner 2005; Villaseñor 2016; Tropicos 2018c); both are poorly represented in herbaria (14 and 4 records, respectively, GBIF 2017b, GBIF 2017c).

Our first objective was to determine if the entire-leaved taxa form a single lineage or multiple ones. We used phylogenetic methods to determine the relationships among these taxa and their relationships to their serrate-leaved congeners. Our second objective was to compare the taxa morphologically to determine whether there are any diagnostic characters distinguishing them. We examined leaf shape and trichome morphology, the characters usually used to separate Trema species. Our third objective was to resolve the taxonomic status of the entire-leaved taxa based on these morphological and phylogenetic data. We reviewed the historical basis for and use of the names in greater detail as a basis for a discussion on the complex taxonomic history of these species, which includes types that are not Trema and types that are mixed collections. Finally, we used our results to provide a new taxonomic treatment for entire-leaved Trema in the Neotropics.

\section{MATERIALS AND METHODS}

Phylogenetic analysis.-Taxon Sampling-Our sampling was structured to address known relationships among Neotropical taxa and to best root and resolve the phylogeny for a discussion of the taxonomic statuses of T. integerrima, T. laxiflora, and T. domingensis. Previous phylogenetic work on Trema indicates a close relationship to Parasponia and that Neotropical species of Trema are likely a clade (Yesson et al. 2004; Yang et al. 2013). Likewise, the work of Yesson et al. (2004) indicates a non-monophyletic T. micrantha.

Four DNA regions (ITS, $r b c L$, trnH-psbA, and $\operatorname{trnL}-F$ ) were insufficient to support relationships within New World Trema (unpub. data), but adding a fifth region (ETS) provided higher support. We selected 24 Trema specimens from Central America and the Caribbean, the most species-rich region for Neotropical Trema. For Trema integerrima, we chose six typical specimens collected from Belize to Panama. For T. domingensis, we include Ekman 12293, collected in 1929, one of only three known collections of this species. We were unable to obtain all five regions from Ekman 15720 and did not sample Fuertes 312, the type. For T. laxiflora, we included Lundell 16311, a paratype collected in 1959. For most other clades of Neotropical Trema, we chose three representative specimens. Trema cubensis was represented by one specimen because we were unable to obtain all five DNA regions from other specimens. For outgroups, we included three Old World species of Trema and two species of Parasponia, the presumed sister taxon to Trema.

DNA Extraction, Amplification \& Sequencing-Samples were either freshly collected with leaf material preserved in silica gel (Chase and Hills 1991) or removed from herbarium specimens with institutional permission. Genomic DNA was extracted using a modified CTAB technique (Doyle and Doyle 1987), scaled to a 1 $\mathrm{mL}$ volume reaction with approximately $10 \mathrm{mg}$ of dried, pulverized tissue, then incubated in $1 \mathrm{~mL}$ of CTAB $2 \times$ buffer and $10 \mu \mathrm{L}$ of proteinase-K for 2 hours at $55^{\circ} \mathrm{C}$. After a chloroform/isoamyl alcohol (24:1) mix with the CTAB solution and centrifugation, the supernatant was purified on silica columns (Epoch life sciences, Inc., Missouri City, TX) to remove any inhibitory secondary compounds (Neubig et al. 2014).

We sampled the plastid loci $r b c L$, trnH-psbA intergenic spacer, and trnL-F intron and intergenic spacer, as well as nuclear ribosomal ITS (internal transcribed spacers, including ITS $1+5.8 S+$ ITS 2) and ETS (external transcribed spacer). Amplifications (PCR) were performed using a SimpliAmp ${ }^{\mathrm{TM}}$ thermal cycler (Life 
Technologies, Carlsbad, CA) and either with GoTaq ${ }^{\circledR}$ Promega (Madison, WI) brand reagents (for trnL-F, rbcL, ITS and ETS) or with Phusion ${ }^{\circledR}$ New England Biolabs (Ipswich, MA) brand reagents (for trnH-psbA only) in $\sim 25 \mu \mathrm{L}$ volumes.

For $\operatorname{trnL}-\mathrm{F}, r b c \mathrm{~L}$, ITS and ETS, the PCR components included $1 \mu \mathrm{L}$ template DNA ( 10-100 ng), $16.5 \mu \mathrm{L}$ water, $5 \mu \mathrm{L} 5 \times$ buffer (which includes $\mathrm{MgCl}_{2}$ at $7.5 \mathrm{mM}$ ), $1.5 \mu \mathrm{LgCl}_{2}(25 \mathrm{mM}), 0.5 \mu \mathrm{L}$ of $10 \mu \mathrm{M} \mathrm{dNTPs}, 0.5 \mu \mathrm{L}$ each of $10 \mu \mathrm{M}$ primers (Table 1), and $0.15 \mu \mathrm{L}$ (0.5 units) polymerase. For trnH-psbA, the PCR components included $2 \mu \mathrm{L}$ template DNA ( 10-100 ng), $14.5 \mu \mathrm{L}$ water, $5 \mu \mathrm{L} 5 \times \mathrm{HF}$ buffer (which includes $\mathrm{MgCl}_{2}$ at $7.5 \mathrm{mM}$ ), $2 \mu \mathrm{LgCl}_{2}$ ( $25 \mathrm{mM}$ ), $0.5 \mu \mathrm{L}$ of $10 \mu \mathrm{M}$ dNTPs, $0.5 \mu \mathrm{L}$ each of $10 \mu \mathrm{M}$ primers (Table 1 ), and $0.2 \mu \mathrm{L}(0.5$ units) polymerase.

Nuclear loci: ITS and ETS were amplified using the PCR conditions $98^{\circ} \mathrm{C}, 2 \mathrm{~min} ; 35 \times\left(95^{\circ} \mathrm{C}, 15 \mathrm{~s} ; 55^{\circ} \mathrm{C}\right.$, $\left.15 \mathrm{~s} ; 72^{\circ} \mathrm{C}, 1 \mathrm{~min}\right) ; 72^{\circ} \mathrm{C}, 3 \mathrm{~min}$ with the primer combinations $\mathrm{A}+\mathrm{B}$, or as two amplicons using $\mathrm{A}+\mathrm{C} \& \mathrm{~B}+\mathrm{D}$ in low quality samples, for ITS and primers ETSF + 18SR for ETS.

Plastid loci: For trnH-psbA, the PCR conditions $98^{\circ} \mathrm{C}, 2 \mathrm{~min} ; 36 \times\left(98^{\circ} \mathrm{C}, 10 \mathrm{~s} ; 55^{\circ} \mathrm{C}, 15 \mathrm{~s} ; 72^{\circ} \mathrm{C}, 1.5 \mathrm{~min}\right)$; $72^{\circ} \mathrm{C}, 3$ min were used with the primer combinations F + R. For trnL-F, the PCR conditions $94^{\circ} \mathrm{C}, 2 \mathrm{~min} ; 33 \times$ $\left(94^{\circ} \mathrm{C}, 30 \mathrm{~s} ; 56^{\circ} \mathrm{C}, 30 \mathrm{~s} ; 72^{\circ} \mathrm{C}, 1 \mathrm{~min}\right) ; 72^{\circ} \mathrm{C}, 3$ min were used with the primer combinations $\mathrm{C}+\mathrm{F}$, or as two amplicons using $\mathrm{C}+\mathrm{D} \& \mathrm{E}+\mathrm{F}$ in low quality samples. For $r b c L$, the $\mathrm{PCR}$ conditions $95^{\circ} \mathrm{C}, 1 \mathrm{~min} ; 35 \times\left(95^{\circ} \mathrm{C}\right.$, $\left.15 \mathrm{~s} ; 55^{\circ} \mathrm{C}, 15 \mathrm{~s} ; 72^{\circ} \mathrm{C}, 1 \mathrm{~min}\right) ; 72^{\circ} \mathrm{C}, 3$ min were used with the primer combinations rbcLZ1 + rbcL3', or rbcLaF $+\mathrm{rbcLaR}$ for low quality samples.

Data Editing \& Phylogenetic Analysis—Sequences were edited, aligned using MAFFT (Katoh et al. 2002) and then manually adjusted in Geneious v. 9.1 .5 (www.geneious.com; Kearse et al. 2012). Initial maximum parsimony and maximum likelihood analyses were carried out in PAUP* (Swofford 2002) and RAxML (Stamatakis et al. 2014), respectively, on the separate datasets to test for topological incongruences by visual inspection. As no strong topological incongruences (bs $\geq 70$; Seelanan et al. 1997) were recovered, we carried out a maximum likelihood analysis on the combined dataset. We selected models and partitioned the data using ModelFinder (Kalyaanamoorthy et al. 2017), where each of the five datasets was a different partition (except for $r b c L$, the only protein-coding region included, in which each codon position was designated a separate partition) in IQ-TREE (Nguyen et al. 2016) and 100 bootstrap replicates on the IQ-TREE webserver (Chernomor et al. 2016; Triffinopoulos et al. 2016). All sequence data have been deposited in GenBank (see Table 2 for accession numbers) and Dryad Digital Repository (Garwood et al. 2018).

Morphological analysis. - We focused on vegetative morphology because Neotropical Trema species are typically distinguished by leaf characters (e.g., Standley 1933; Nicolson 1991; Todzia 2001; Legaard \& Balslev 2014; Nee 2015), not reproductive characters. Analysis of leaf trichomes and/or leaf shape have proved useful in distinguishing species of Trema in Africa (St-Laurent et al. 2000a, 2000b) and the Neotropics (Gardiner 1965).

Leaf Morphometric Analysis-To determine whether leaf shape differs among the three entire-leaved species, and whether these differ from other Trema species, we performed a morphometric analysis. We measured blade length (BL), blade width (BW), distance from base of blade to the widest part (BD), indentation of blade from apex of petiole to base of blade (BI), apex length (measured from change in blade curvature to tip of apex $(\mathrm{AL})$, petiole length $(\mathrm{PL})$, and tooth density (number/cm; TD) on three mature leaves per specimen (smallest, largest, and one intermediate-sized). Of the entire-leaved specimens cited in the taxonomic description, 48 (marked $\ddagger$ ) had sufficient mature, well-pressed leaves for measurement: T. integerrima $(\mathrm{N}=41)$, T. laxiflora $(\mathrm{N}=2)$ and $T$. domingensis $(\mathrm{N}=5)$. We compared these to specimens from T. cubensis $(\mathrm{N}=7)$, T. lamarckiana $(\mathrm{N}=37)$ and the polyphyletic T. micrantha $(\mathrm{N}=173)$, which are listed in the Appendix. Measurements were taken from specimens using a mm ruler and from images using ImageJ (Rasband 1997-2016). Raw morphometric data are available from the Garwood et al. (2018). Across species, blade length was highly correlated with blade width, distance to widest part, apex length, and petiole length; therefore, we calculated the ratio of these characters to blade length to get size-independent measures of leaf shape (BW/BL, BD/BL, BI/BL, AL/BL, and PL/ BL). We did a Principle Components Analysis (PCA) using Systat (2009) using the correlation matrix, and graphed the standardized principal component scores. 
TABLE 1. Primers used in this study.

\begin{tabular}{cll}
\hline Locus/Primer & Primer sequence & Reference \\
\hline ITS & & \\
ITS A & CGAGAAGTCCACTGAACCTTATC & \\
ITS B & TCTTYTCCTCCGCTTATTGATATGC & Abbott (2009) \\
ITSC & GCGTTCAAAGACTCGATGGTTC & Abbott (2009) \\
ITSD & GACTCTCGGCAACGGATATCTCGGC & Abbott (2009) \\
ETS & & Abbott (2009) \\
ETSF & CGTTCGGTTTCCTGTGTTGG & \\
18SR & TACTGGCAGGATCAACCAGG & This paper \\
trnL-F & & This paper \\
C & CGA AAT CGG TAG ACG CTA CG & \\
D & GGG GAT AGA GGG ACT TGA AC & Taberlet et al. (1991) \\
E & GGT TCA AGT CCC TCT ATC CC & Taberlet et al. (1991) \\
F & ATT TGA ACT GGT GAC ACG AG & Taberlet et al. (1991) \\
trnH-psbA & & Taberlet et al. (1991) \\
F & TGATCCACTTGGCTACATCCGCC & \\
R & GCTAACCTTGGTATGGAAGT & Xu et al. (2000) \\
$r b c L$ & & Xu et al. (2000) \\
rbcL Z1 & & \\
rbcL 3' & ATGTCACCACAAACAGAAACTAAAGCAAGT & Clayton et al. (2007) \\
rbcLaF \\
rbcLaR & CTCGGAGCTCCTTTAGTAAAGATTGGGCCGA & Clayton et al. (2007) \\
\hline
\end{tabular}

Trichome Morphology Imaging-To examine the micromorphology of leaves among the entire-leaved species of Trema, we used light microscopy (LM) and scanning electron microscopy (SEM) from herbarium specimens. For SEM, carbon adhesive strips were placed on aluminum SEM stubs, tissues were placed on adhesive, then placed in a desiccation chamber for 24 hours. Samples were sputter coated, then imaged on the scanning electron microscope. For LM, specimens were imaged on an Olympus SZ-6145 dissecting microscope. Trichome length in the SEMs was measured using ImageJ (Rasband 1997-2016).

\section{RESULTS}

Phylogeny.-We present a 5-gene tree (Fig. 1) for 24 specimens of New World Trema (Table 2) from Central America and the Caribbean, including specimens of all the entire-leaved species: T. integerrima, T. laxiflora and T. domingensis. As found previously (Yesson et al. 2004), there was high support for a Neotropical clade of Trema $(\mathrm{BS}=100)$ and T. micrantha was polyphyletic. Within the Neotropical clade, there was strong support (BS=100) for an entire-leaved clade that included T. integerrima, T. laxiflora and T. domingensis with little sequence variation among specimens in this clade. The entire-leaved clade was distinct from T. lamarckiana (Roem. \& Schult.) Blume, T. cubensis Urb. and four clades of T. micrantha, all of which had high support (BS=100), except for the single specimen of T. cubensis.

Morphology.-Leaf morphometrics-The PCA used seven leaf measurements (BL, TD, BW/BL, BD/BL, BI/BL, $\mathrm{AL} / \mathrm{BL}$, and PL/BL) from all three measured leaves per specimen. The first two axes explained $48 \%$ of the variation among specimens. All variables had component loadings $>0.5$ on axis 1 or 2 except BD3/BL3 (= 0.435). This analysis indicated that entire-leaved specimens can easily be separated from other Neotropical Trema species (Fig. 2A). When tooth density was removed from the analysis, the ellipse for the entire-leaved clade shifted into T. micrantha (occupying about a third of that ellipse), but T. cubensis and T. larmarckiana remained distinct (see Garwood et al. 2018, Fig. S1). This indicates that the entire margin of this clade is a critically defining character, but also that leaf shape of the entire-leaved clade is similar to only a subset of the polyphyletic $T$. micrantha. The component loadings for each variable from the different leaves (e.g., BL1, BL2, BL3) clustered tightly together (see Garwood et al. 2018, Fig. S2), suggesting that a single leaf or the average of three leaves 


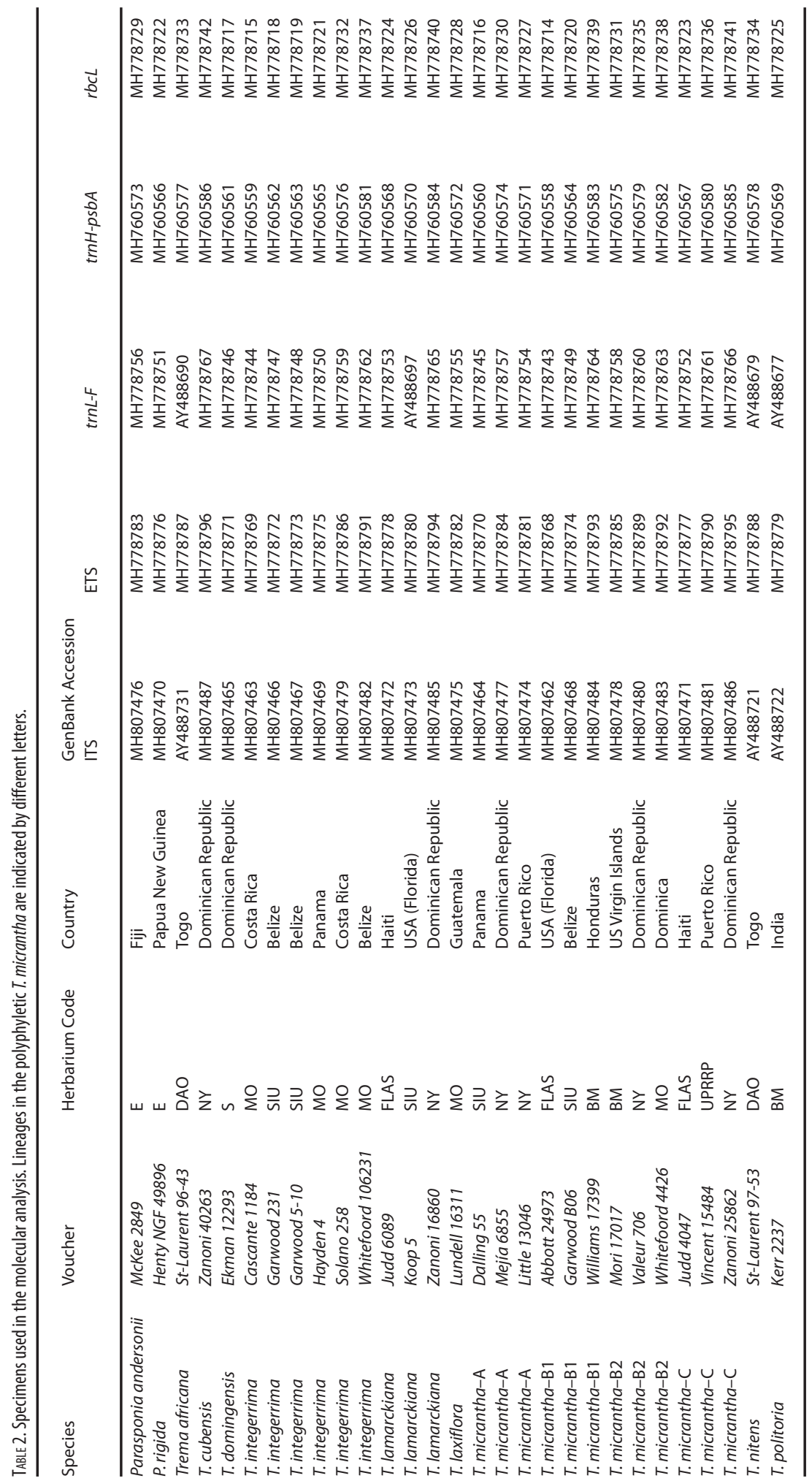

This document is intended for digital-device reading only. 


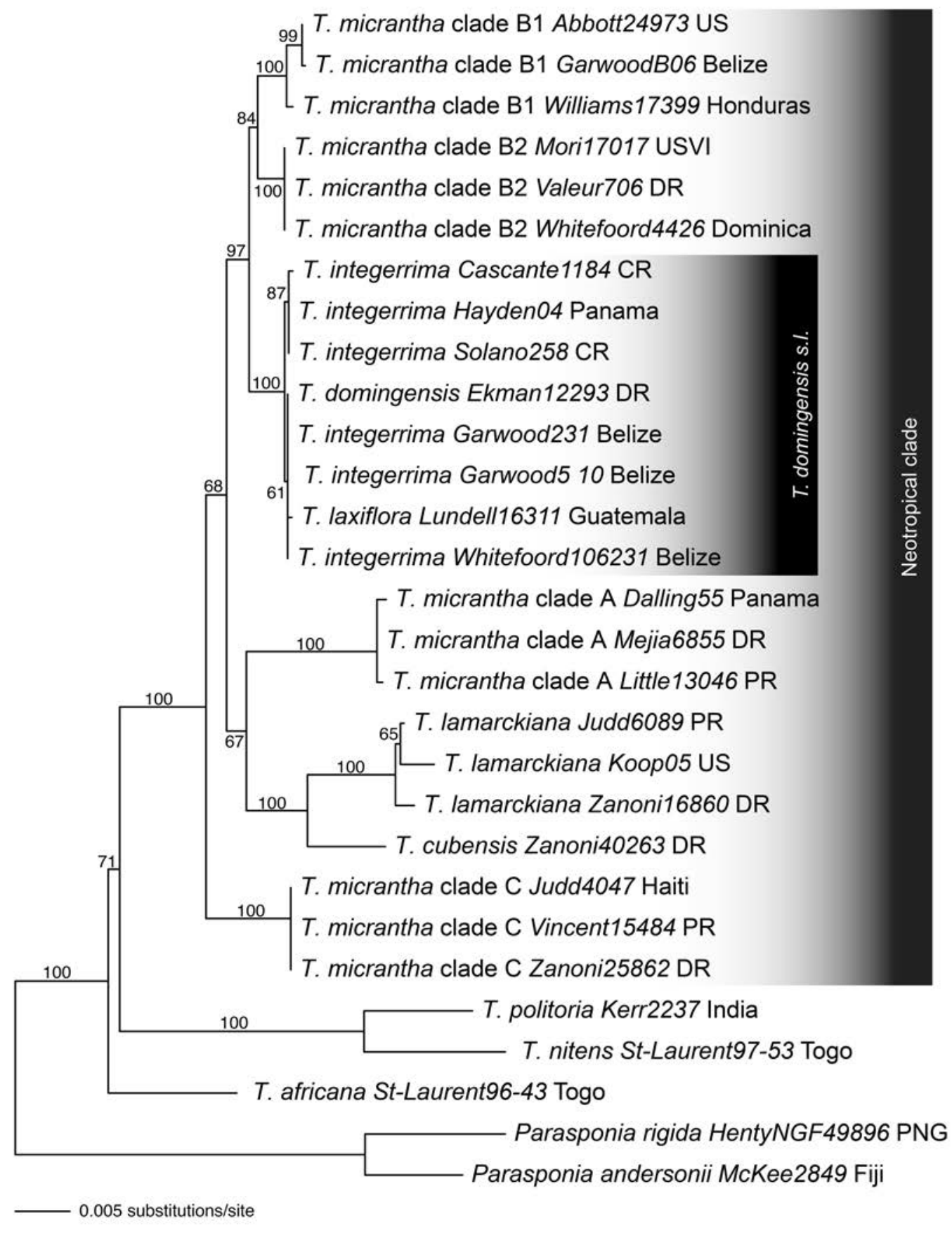

FIG. 1. Best tree found in a maximum likelihood search using IQ-TREE. Bootstrap values for each node are indicated, if greater than $50 \%$. Gray bar indicates the Neotropical clade of Trema. Black bar indicates T. domingensis s.I. (including T. domingensis, T. integerrima, and T. laxiflora), which forms a clade with little internal resolution. Country abbreviations: US = United States; USVI = US Virgin Islands, DR = Dominican Republic, $\mathbf{C R}=\mathbf{C o s t a}$ Rica; PR = Puerto Rico, PNG = Papua New Guinea. 

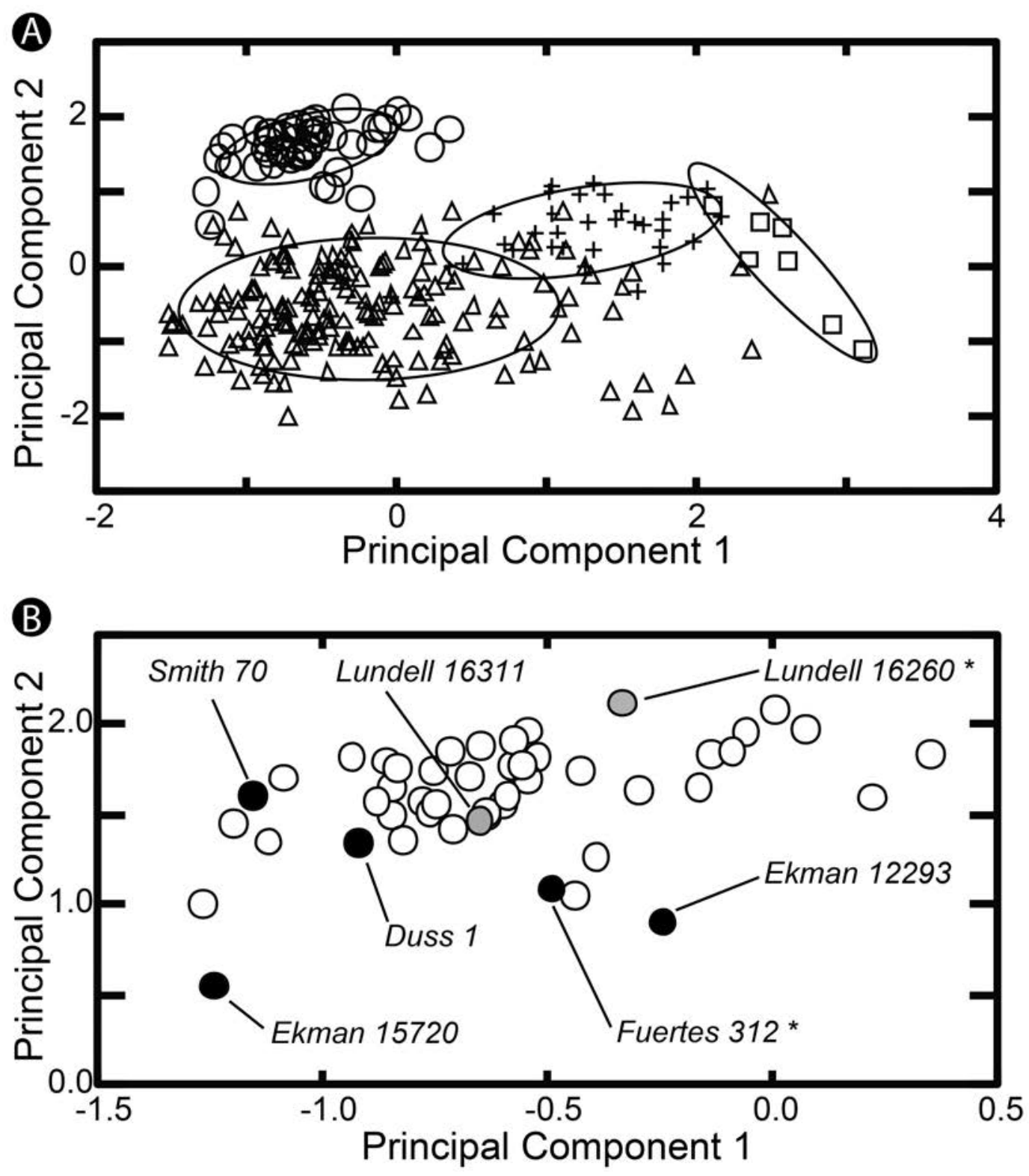

FIG. 2. PCA analysis of leaf shape. (A) All Neotropical species: circles: entire-leaved species (T. integerrima, T. domingensis, T. laxiflora); squares: $T$. cubensis; crosses: T. lamarckiana; triangles: T. micrantha. Sample Gaussian confidence ellipses are shown (using default $p=0.68$ ) to highlight positions of clades. (B) Expanded detail for entire-leaved species: open circles, T. integerrima; black circles: T. domingensis (includes 2 other Caribbean specimens); gray circles: T. Iaxiflora; *: type specimens. 
might suffice in the analysis. However, including data from all three leaves provided the best separation of the entire-leaved species from other Trema (see Garwood et al. 2018, Fig. S3).

The type of T. domingensis (Fuertes 312) from the Dominican Republic and two specimens from Martinique and St. Vincent (Duss 1 and Smith 70, respectively), as well as the type and paratype of T. laxiflora (Lundell 16260 \& Lundell 16311, respectively) from Guatemala, all fell within the range of variation seen in the mainland $T$. integerrima (Fig. 2B). The two Ekman specimens from Dominican Republic were somewhat outside the range of most other specimens in the clade (Fig. 2B), but were still separate from nearly all T. micrantha specimens (Fig. 2A).

Leaf trichomes-We present SEMs of the leaf indumentum (Fig. 3) for one typical specimen of T. integerrima (Garwood 5-10) and T. domingensis (Ekman 12293) and LMs of T. domingensis (Fuertes 312, type) and T. laxiflora (Lundell 16311, paratype). These specimens have short appressed trichomes (mostly $\leq 0.25 \mathrm{~mm}$ long) on the abaxial surface of the blade, each with an enlarged base sunken into the epidermis. Trichome length on the blade (mean \pm SD: $0.14 \pm 0.035 \mathrm{~mm}$, range: $0.08-0.19, \mathrm{~N}=10)$ and veins $(0.22 \pm 0.058 \mathrm{~mm}, 0.11-0.32)$ of Ekman 12293 was slightly longer than on blades $(0.12 \pm 0.028 \mathrm{~mm}, 0.08-0.16)$ and veins $(0.19 \pm 0.058 \mathrm{~mm}$, 0.11-0.29) of Garwood 5-10, but these differences were not significantly different (t-test: $\mathrm{t}=-1.86$ and -1.02 , respectively, $\mathrm{df}=36, \mathrm{p}>0.05$ ). These trichomes give the leaves a soft silky texture, not a scabrid texture. Trichome density was somewhat lower in the Ekman and Fuertes specimens of $T$. domingensis than the Garwood and Lundell specimens, but these represented the range of variation seen in other specimens examined. Leaves on young plants (height $<2 \mathrm{~m}$ ) were sometimes toothed, but had the characteristic appressed trichomes on the lower surface. No other species or clade of Neotropical Trema had both the characteristic minute appressed trichomes on the lower surface of the blade and entire leaf margins, based on specimens examined (Appendix) and literature on Neotropical Trema reviewed for this study.

\section{DISCUSSION}

These phylogenetic results indicate that T. integerrima, T. domingensis and T. laxiflora form a well-supported clade with little sequence variation within specimens. The morphological analysis found no diagnostic differences among them. We therefore conclude that the morphologically and phylogenetically similar $T$. integerrima, T. laxiflora and T. domingensis are conspecific. In applying a name to this clade, dates of publication should give precedence to $T$. integerrima, a name now commonly used for this widespread species. However, this simple solution is incorrect. We discuss below how several complicated quirks of history and nomenclature lead to a different solution.

Beurling's Sponia integerrima-Sponia integerrima Buerl. (1854 [1856]:144) is the basionym for Trema integerrima. The type specimen is J.I. Billberg 308 (S), collected in April 1826 in Porto Bello [Portobelo], Panama. On his return from Panama, Johan Immanuel [Emmanuel] Billberg prepared a list of species collected, but died without publishing it. Beurling (1856) described 203 species collected by Billberg as Primitiae Florae Portobellensis, which he had presented two years earlier (1854). There are two sheets of Billberg 308 at Stockholm: S14-20231 and S14-20301, both marked "Typus". No other sheets of Billberg 308 were located after extensive searching in about 35 additional on-line databases. (Billberg's main collection is at S fide Stafleu \& Cowan (1976), where 185 sheets from Portobelo have been databased. We found 22 additional Billberg sheets from Panama in other herbaria: B, CAS, F, HAL, LD, NY, UPS, and US [negatives from B], but not Billberg 308). The label information from the Billberg types is summarized below:

S14-20231—Original text: No. 308, Celtis [mostly overwritten by Boehmeria], Porto Bello, Apr 1826, J.Bbg [JIBgl?]. Later annotations: Herb. Wikströmii, Boehmeria; Sponia integerrima Beurl. in act. holm. [Wikström annotation fide S]

S14-20301-Original text: No. 308, Porto-Bello, in montibus, Apr 1826. Later annotations: Sponia, Billberg 

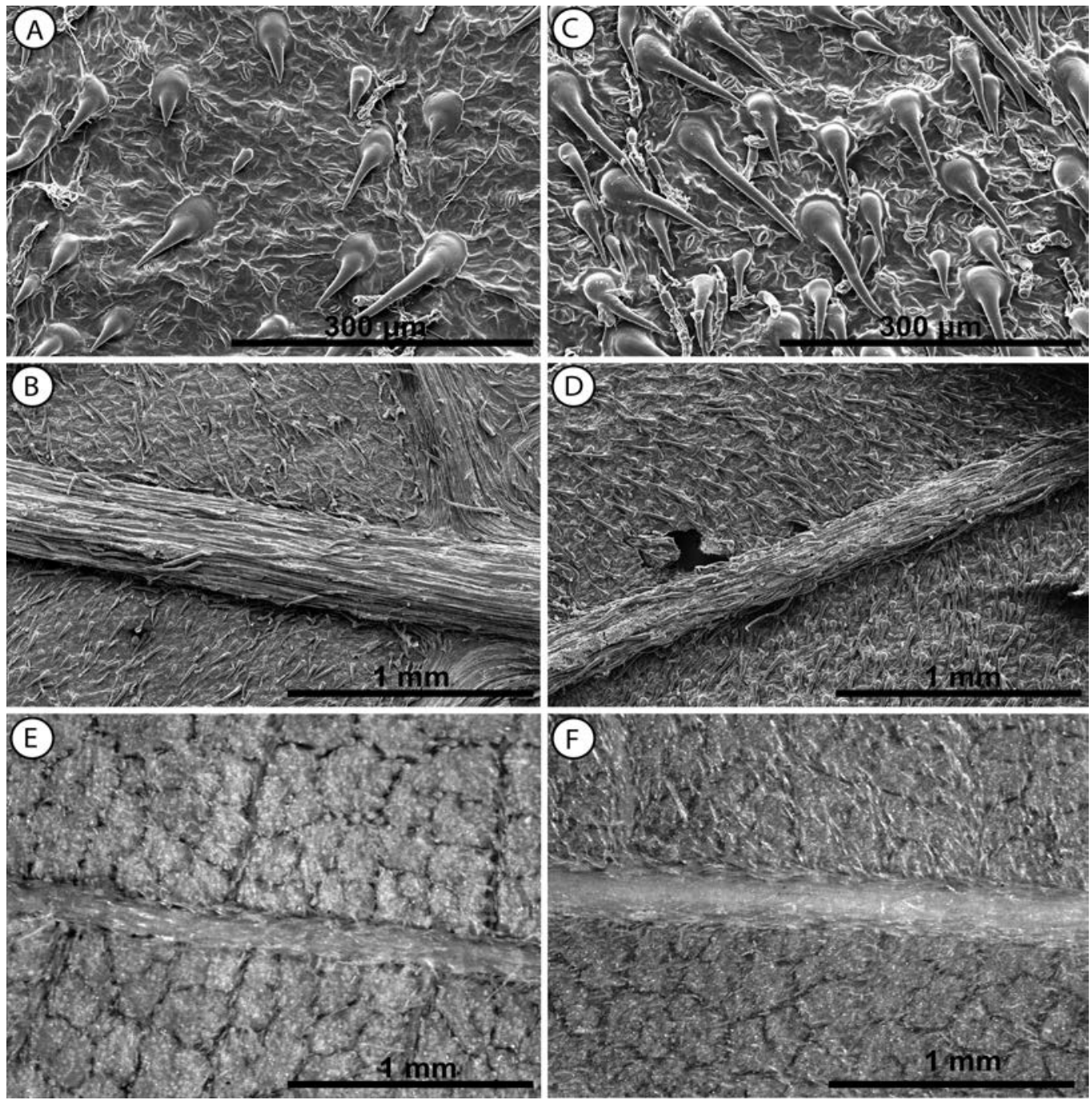

FiG. 3. Leaf abaxial hair morphology of entire-leaved species of Trema. Scanning electron micrographs of (A-B) T. domingensis, Ekman 12293 (S) and (C-D) T. integerrima, Garwood 5-10(SIU). Light micrographs of (E) Fuertes 312, T. domingensis (isolectotype, NY) and (F) Lundell 16311, T. laxiflora (paratype, M0).

The faint handwriting of the original text on S14-20231 appears on many other Billberg specimens at S, in the same faint ink with only minor differences (e.g., different collection numbers, sometimes the JI more distinct or the last name in full), so we presume that it was written by Billberg (or his collecting companion Dahlin). Later annotations are in other hands. The writing on S14-20301 is in two hands. The original text on S14-20301 differs from the original text on S14-20231: if it is also by Billberg, it was penned at a different time. While several recent floristic treatments indicate that the holotype of Sponia integerrima is at S (Legaard \& Balslev 2014:66; Nee 2015; Tropicos 2018a), they do not report that there are two specimens of Billberg 308 at $S$ or designate which is the holotype. Therefore, we here designate S14-20231 as the lectotype, as it most likely was annotated by Billberg himself, and S14-20301 as the isolectotype.

Beurling clearly had doubts about his generic identification of Billberg 308. He used a question mark after the genus (Sponia?) and noted that in general habit the plant was similar to shrubby species of Boehmeria. (He 
used a question mark after his designated genera only two other times in the 203 species treated; both were placed in the correct family.) Beurling attributes an early identification of the specimen as "Celtis?" to Billberg. We were initially unsure whether this information came from Billberg's notes or the specimens, but faint lettering underneath "Boehmeria" on S14-20231 is "Celtis." It is in the same hand and ink as other data on the original label (lending further support to Billberg as the author of the original text on S14-20231). No question mark can be detected on the label, so we assume that Beurling was also doubtful of Billberg's Celtis identification. In Billberg's time, a broadly defined Celtis L. would have included most of what we now delimit as Cannabaceae (excluding Cannabis and Humulus); a still broadly defined Sponia Comm. ex Decne. was split from Celtis in 1834. Thus, Beurling had doubts that the specimen was Trema or a closely related genus.

We carefully examined the high-resolution images of both type specimens of Sponia integerrima available on-line at Stockholm. Neither specimen of Billberg 308 is a Trema nor any other taxon in Cannabaceae, but both are instead Urticaceae. Using the recent Urticaceae treatment in Flora Mesoamerica (Munro 2015; Wilmot-Dear et al. 2015), we identify them as Pouzolzia obliqua (Wedd.) Wedd., a species known from Panama and widespread in Central America and northern South America. The basionym of P. obliqua (Wedd.) Wedd. (1857:405-406) is Margarocarpus obliquus Wedd. (1854:204). The type, E.F. Poeppig 2032 collected in Peru in 1830, was originally annotated Boehmeria obliqua Peopp. (now considered an invalid synonym). The Billberg specimens are very good matches to the types (Holotype: P, P00605601; Isotypes: F, 870586, 1 leaf; F, negative 31083 of W; internet images!).

Beurling's doubts about the identification of Billberg 308 were clearly well-founded. We can gain some insight into why Beurling chose "Sponia?" rather than a genus in Urticaceae by examining what material was available to him at the time in Stockholm, assuming he had access to the important personal collections of the period. Pouzolzia obliqua was probably unknown to Beurling at this time as the basionym was published in 1854, and the current name in 1857. He did not travel widely (Stafleu \& Cowan 1976:210), so was unlikely to have seen specimens in Paris and Vienna that became types. The first P. obliqua specimen in Stockholm was not collected until about 1900 (J. Lundberg (S), pers. comm. 2017). Pouzolzia Gaudich., however, had been published (Gaudichaud-Beaupré, 1826 [1830]:503) and a handful of species described before 1850, all from the Old World (see Weddell 1854, 1857, excluding species described by Wight 1853). Using the on-line catalogs for S (Naturhistoriska Riksmuseet, continuously updated) and SBT (Bergius Botanic Garden, continuously updated), in which much of the historic material in question has been databased, we found that ten Pouzolzia specimens were present in Stockholm before 1850 (S), identified at the time as Urtica, Parietaria, or Memorialis, including P. laevigata (Poir) Gaud, P. zeylanica (L.) Benn. \& R. Br., P. pentandra (Roxb.) Benn. \& R. Br. and P. guineensis Benth. These specimens share congested axillary inflorescences and entire leaves with Billberg 308, and several have persistent bracts subtending the inflorescences, but not the shrubby habit and larger leaves with oblique bases. Other Urticaceae were also well represented (> 100 specimens). The most similar to Billberg 308 was the Neotropical Boehmeria ramiflora Jacq. with at least 13 specimens present before 1850 (S, SBT): many of these were annotated as B. ramiflora by Wikström before 1856 (the year of his death) and were probably familiar to Beurling. These have the same congested axillary inflorescences with persistent bracts and slightly zig-zagged stems as Billberg 308, but distinctly toothed leaves and long petioles. Whoever wrote Boehmeria over Celtis on S14-20231 recognized that the specimen was similar to but distinct from the common B. ramiflora. This annotation is probably the source of Beurling's comment that the specimen is similar to shrubby Boehmeria.

Neotropical Sponia (now Trema) were also well represented in Stockholm before 1850, with at least 12 specimens collected in the New World (S, SBT), mostly in the Swartz herbarium. These were initially identified as Celtis species, then updated to Sponia sometime after Decaisne (1834) transferred them to Sponia but before Wikström's death in 1856, as Wikström made many of the Sponia annotations (fide S). No Sponia specimens had been annotated as Trema, a change made by Blume (1856). In contrast to Billberg 308, the Sponia specimens have toothed leaves (albeit more delicate than those of Boehmeria) and more open inflorescences that lack persistent bracts. But they also had relatively large lanceolate leaves, with short petioles and oblique bases, and 
were woody. Beurling presumably opted for Sponia because the overall gestalt of the Billberg 308 specimens better matched the Sponia specimens in Stockholm compared to specimens of Urticaceae later assigned to Pouzolzia or Boehmeria. It is also possible that the floral or fruit structures needed to identify it as Urticaceae were absent; no details were provided in Beurling's description. Even today, specimens of P. obliqua are not infrequently misidentified as Trema (Croat 1978; and, e.g., Villa \& Garwood 2146, Ecuador (QCA, SIU); Vieira et al. 452, Brazil (MO)).

Whatever Beurling's reservations about the generic identification, publication of Sponia integerrima was quickly noted (Anon. 1856:266). Planchon (1873), however, excluded it from his treatment of Ulmaceae as unknown [ign.]. Hemsley (1883:40) treated Sponia? integerrima Beurling as a "doubtful plant" under Trema in his summary of Central American plants. Sponia integerrima appeared in the first edition of Index Kewensis in 1895 (Jackson 1895, Vol 2(2):969). By that time, species of Sponia were considered synonyms of Trema, Celtis, Aphananthe, Parasponia or Gironniera. A handful of names in the list, including S. integerrima, had not yet been assigned to a genus, indicating that no-one had further studied the species. It did not reappear in Index Kewensis until 1938 (suppl. 9, Hill 1938:286) after Standley (1933) used it as a basionym.

Standley's Trema integerrima-Standley (1933:55) used the new combination Trema integerrima (Beurl.) Stand, basionym Sponia integerrima Beurl., for a new species in his updated The Flora of Barro Colorado Island [Panama]. It was slow to be accepted, in spite of Standley's insistence that this species was "strikingly distinct from the various forms of T. micrantha in its entire leaves." Even in Panama, it was considered a synonym of $T$. micrantha in Flora of Panama (Nevling 1960), a revised Flora of Barro Colorado (Croat 1978), and the Panama Checklist (D’Arcy 1987), but was finally accepted in Catálogo de las Plantas Vasculares de Panamá (Correa et al. 2004). Trema integerrima was first embraced by tropical foresters working in western Ecuador (Little 1948; Little \& Dixon 1969). Elsewhere, it was sometimes considered a synonym of T. micrantha (Carauta 1974; Navarro Gomez 2013) or initially overlooked as a species in countries where it has since been reported (Standley \& Record 1936; Standley 1937; Standley \& Steyermark 1946; Foster 1958; Burger 1977; Seymour 1980; Dwyer \& Spellman 1981; Berg 1992, 1997), perhaps because of few collections. It has gradually been accepted as a valid species throughout Central and South America (Lasser 1971; Molino Rosito 1975; Dodson \& Gentry 1978; Holst \& Todzia 1990; Brako \& Zarucchi 1993; León-Yánez 1999; Balick et al. 2000; Todzia 2001; Pennington et al. 2004; Grandter 2005; Miller \& Berry 2005; Clark et al. 2006; Berg et al. 2007; Vargas \& Idarraga 2011; Grandtner \& Chevette 2013; Legaard \& Balslev 2014; Mayta et al. 2014; Nee 2015; Tropicos 2018b.)

Given the now widespread acceptance of the species, why has no one previously noticed that Sponia integerrima, the basionym of Trema integerrima (Beurl.) Stand, is not a Trema? Simply put, it seems nobody had examined the type specimen, Billberg 308. In proposing his new combination, Standley (1933:55) noted that the Central American collections he was examining "apparently are referable to this species." He added that "Sponia integerrima has remained unknown since its description, probably because no specimens of it were available to students of the genus," indicating that he did not know if the type existed or where it was. He did not mention the Billberg specimen. One also wonders whether Standley (1933) read Beurling's account carefully, as he failed to comment on Beurling's doubts about the identification, its comparison to Boehmeria, or how his specimens differed from Beurling's description. For example, Beurling described the leaves not only as "integerrimis" but also "scabris," and the bases as "basi laeviter cordata inaequali" which does not apply to specimens of $T$. integerrima we have examined.

No authors before or after Standley (1933) reported examining the type of Sponia integerrima. Planchon (1873) and Hemsley (1883) presumably dismissed the species because the type or other specimens were unknown. (If Hemsley had seen the type, he might have realized it was Pouzolzia obliqua Wedd., which he listed from a site in Panama only $60 \mathrm{~km}$ from Portobelo.) Urban (1912) compared T. domingensis to Beurling's description of S. integerrima, and concluded they were different species, but does not mention examining the Billberg type. Lundell (1960) noted that the relationship of T. laxiflora to T. integerrima "remains to be determined", but also did not report examining the Billberg type or even the specimens cited by Standley (1933). 
Subsequent authors followed Standley's lead in using T. integerrima, all without examining the type or reading the type description carefully themselves. Of those authors cited above that recognized T. integerrima, only a few mention Sponia integerrima as a synonym (Zarucchi \& Todzia 1993; Leon-Yanez 1999; Todzia 2001; Grandtner 2005; Berg et all 2007; Vargas \& Idarraga 2011; Grandtner \& Chevette 2013; Legaard \& Balslev 2014; Mayta et al. 2014; Nee 2015; Tropicos 2018a,b). Only Legaard and Balslev (2014), Nee (2015) and Tropicos (2018a) note that the Billberg holotype is at S. Legaard and Balslev (2014) explicitly state that they did not examine it. The recent widespread availability of on-line type images, specimen databases and botanical literature has allowed us to examine Billberg 308 and rectify this decades-long error.

Standley was correct, however, in recognizing a species that was distinct from T. micrantha. We have examined images of the three specimens cited by Standley (1933) as T. integerrima: Aviles 58 (Barro Colorado Island, Panama; 1931; MO-188719; accession: 1953144), Cooper \& Slater 18 (Changuinola Valley, Panama, 1927; US 01926461), and Standley 54097 (Lancetilla Valley, Honduras; 1927-1928: F 582173, US 01926462). In his Flora of the Lancetilla Valley, Honduras, Standley (1931) mentioned that T. micrantha was sometimes "nearly entire", but had not yet concluded that this represented a different species. Even though Standley 54097 and Cooper $\&$ Slater 18 are sterile, and Aviles 58 has scant reproductive material remaining, all three collections are clearly the entire-leaved Trema that is now widely recognized as T. integerrima and not T. micrantha. Other than noting the entire leaves, Standley (1933) provided no further description of T. integerrima, which perhaps accounts for its slow recognition, nor a comparison to the previously described entire-leaved T. domingensis.

It is clear from this examination that although Trema integerrima sensu Standley (1933) clearly corresponds to the entire-leaved Trema species prevalent in Central and South America, the nomenclatural basis is formed on type specimens that do not fit Trema at all. Of the two alternate names available, T. domingensis Urb. (1912) and T. laxiflora Lundell (1960), T. domingensis has priority.

Lundell's Trema laxiflora-Lundell based Trema laxiflora Lundell (1960) on two of his own collections from the Petén, Guatemala: Lundell 16260 (Holotype: LL: LL00370454, now at TEX; isotypes: LL: LL00370453 and S: S-R-6173) and Lundell 16311 (MO), cited in the protolog, is a paratype. Trema laxiflora is rarely cited. Nee (2015), The Plant List (2013) and Tropicos (2018c) consider it a synonym of T. integerrima. In recent ecological or floristic works for Chiapas, Mexico, and/or the Petén, Guatemala, however, it has been used instead of $T$. integerrima (Grandtner 2005; Lohbeck 2010; Breugel et al. 2012; Villaseñor 2016), but at least one Chiapas specimen has been redetermined as T. integerrima (Martínez et al. 25233, MEXU, internet image). Both Lundell (1960) and Urban (1912) provided detailed descriptions of their proposed species, in contrast to Standley (1933), and their descriptions are very similar. For example, both note that the pubescence on the lower surface of the leaf is finely sericeous or subsericeous (i.e., fine appressed silky hairs). If not for the previously published, but overlooked and rarely collected T. domingensis Urb., which Lundell does not discuss, this would be a fine replacement name for T. integerrima.

Urban's Trema domingensis: Clarifying the type-The type of Trema domingensis Urb. is Fuertes 312 (Urban 1912:191, as domingense). Unfortunately, among the 10 specimen sheets we have found that bear this collection number (Table 3), there are two species represented: T. domingensis and Celtis trinervia Lam. In examining specimens of Trema at US, Gardiner (1965) was the first to identify the toothed specimens of Fuertes 312 at US as $C$. trinervia, but then incorrectly assumed that all $T$. domingensis specimens would be $C$. trinervia. Celtis trinervia appears to be a good match for the second species; for comparison, see the type De Roquefeuil s.n. (P, MNHN-P-P00663149) and also Fuertes 1118 (P, P06885023; US, 698160; K, K000703708; MO, MO707175 [not seen]), all collections from the Dominican Republic.

This problem, that Fuertes 312 represents two species, has not previously been noted because no herbarium has specimens of both species for this collection (Table 3), although images of most of these specimens (except those at Z and USD) are now in JSTOR Global Plants (no date) under Trema domingense. The only C. trinervia in the published list of Fuertes' 1974 collection numbers (Fuertes 1978; Liogier 1978) is Fuertes 1118, collected in 1911 with fruit (Fuertes 312 is in flower). The "312" was probably not a simple transcription error, as none of the species near 312 ( \pm 30 numbers) should have been confused with Celtis or Trema and none of the 
TABLE 3. Information on duplicates of Fuertes 312, type of $T$. domingensis.

\begin{tabular}{|c|c|c|c|c|}
\hline Species & Herbarium Code & Barcode or accession number & Type data on specimen & $\begin{array}{l}\text { Type of T. domingensis } \\
\text { here designated }\end{array}$ \\
\hline \multicolumn{5}{|c|}{ Trema domingensis Urb. } \\
\hline & B & B100247958 & Typus & Lectotype \\
\hline & USD & USD00000069 & Isotype & Isolectotype \\
\hline & NY & 00025180 & Co-type & Isolectotype \\
\hline & NY & 00025179 & $\mathrm{n} / \mathrm{a}$ & Isolectotype \\
\hline & $U$ & U0044459 & Isotype & Isolectotype \\
\hline \multicolumn{5}{|c|}{ Celtis trinervia Lam. } \\
\hline & US & 00089753 & Isotype & Not a type \\
\hline & $P$ & MNHN-P-P00722032 & Isotype & Not a type \\
\hline & z & Z-000028633 & Type & Not a type \\
\hline & G & G00354623 & Typus & Not a type \\
\hline & G & G00354602 & Typus & Not a type \\
\hline
\end{tabular}

54 unnamed collections were likely to have been miswritten as 312 . However, about 175 numbers were duplicated (disambiguated with a-e in the list; Fuertes 1978). Therefore, the mixed collection of Fuertes 312 probably originated with the collector himself. Because Urban was familiar with C. trinervia (Urban 1909), a common Caribbean species described in 1797 , and was unlikely to confuse it with the entire-leaved T. domingensis, we assume that the collection was broken up and distributed prior to the description of $T$. domingensis and that Urban's identifications labels for Fuertes 312 were sent to recipient herbaria at a later date. All of the labels (except B100247958, NY00025180, and USD00000069) were Urban's preprinted labels with "Flora von Santo Domingo, Prov. Barahona", "det. Urban", "Coll. Pater Fuertes" and 1910 or 1911. To avoid further confusion, we list all known specimens of Fuertes 312 and give identification, location and accession numbers (Table 3).

As we have found no records indicating that one of the five known type specimens of $T$. domingensis has been designated as the holotype, we here designate Fuertes 312 at B (B100247958) as the lectotype and the other specimens as isolectotypes (Table 3). It is not only the best-preserved specimen, with abundant floral material, but one that the Berlin-based Urban no doubt used in describing the species. An annotation on the Berlin specimen "a New York abgegeben. VIII 1911. Urban" [delivered to New York], suggests Urban himself sent duplicates to NY in 1911.

Zanoni and Mejía (1989) and García et al. (2001) indicated that T. domingensis s.s. was known only from the type collection and had not been re-collected in spite of efforts to locate it (Zanoni, pers. comm. 2004); Liogier (1996) also only mentioned the Fuertes type. Two additional collections by E.L. Ekman from 19291930 are now known. We list them below, as T. domingensis s.s. is so poorly represented in herbaria:

Ekman 12293: S (S04-933, internet image!), US (00835256, internet image!), and U (U0034891, image provided);

Ekman 15720: S (S15-27092, internet image!), US (00835257, internet image!) and K (no number, image provided).

We reviewed images of all specimens and they match the type of $T$. domingensis s.s. Of these, several have been cited in recent ecological or phylogenetic studies: Ekman 12293 (S, Hager 1990; U, Yang et al. 2013); Ekman 15720 (S \& K, Jerrå 2014). We also located two other historical specimens which were identified as T. micrantha: these can also be considered T. domingensis s.s. based on their Caribbean rather than mainland locale:

Smith \& Smith 70 (BM; imaged by Garwood), collected in 1890 on St. Vincent, cited in Anon. (1893:276); Duss 1 (P: P-MNHN-P-P06885119; internet image!), collected in 1881 on Martinique.

Urban (1920) attributed T. domingensis with doubt to Martinique and/or Dominica, but cited no evidence. This was likely based on a duplicate of Duss 1 in his herbarium. Duss's collection arrived at the Krug \& Urban herbarium badly mixed by other institutions (Urban 1900), so exact locations were unknown, although all were collected in Martinique, Guadeloupe, Dominica and nearby islands. The Paris specimen suggests Martinique 
as the source, assuming no similar confusion there. Duss (1897) himself does not cite the specimen under either T. micrantha or T. lamarckiana. Nicolson (1991) did not find T. domingensis in Dominica. These two collections from the Lesser Antilles considerably expand the range of the species in the Caribbean.

Trema domingensis has generally been overlooked by taxonomists concerned with Trema on the mainland of Central and South America. Neither Standley (1933) nor Lundell (1960) referred to it when describing T. integerrima and T. laxiflora, respectively. It is not listed as a synonym of T. integerrima in any of the Central or South American floras cited above. Grudzinskaya (1993) suggested these two poorly known species might be conspecific, but she had not seen specimens of either species. Ironically, T. domingensis, a species thought to be endemic to the Bahoruco Mountains of Hispaniola (Zanoni \& Mejía 1989; García et al. 2001; AcevedoRodríguez \& Strong 2012), and possibly extirpated (Zanoni \& Mejía 1989), is now recognized from this study as widespread throughout the Neotropics. With its phoenix-like re-emergence, we lose a possibly extinct island endemic, but gain a better understanding of this Neotropical species.

\section{NOMENCLATURE}

Pouzolzia obliqua (Wedd.) Wedd. (as Pouzolsia obliqua), Arch. Mus. Hist. Nat. 9:405-406. 1856[1857]. Margarocarpus obliquus Wedd., Ann. Sci. Nat., Bot., sér. 4, 1:204. 1854. Type: PERU. Loreto: Maynas alto, Jul 1830. "Boehmeria tobliqua Poepp." [nom. inval.] on original label, E.F. Poeppig 2032 (HоLотурE: P [P00605601] internet image!; ISOTYPEs: F [870586 (1 leaf)], $\mathrm{F}$ [negative 31083 of W], internet images!).

Sponia integerrima Beurl., Kongl. Vetensk. Acad. Handl. 40:144. 1854[1856], syn. nov. TyPE: PANAMA: Juxta urbem Portobello [Porto Belo] Americae centralis, in montibus, Apr 1826, J.I. Billberg 308 (LECTOTYPE, here designated: S [S14-20231] internet image!; ISOLECтотуPE, here designated: S [S14-20301] internet image!). Trema integerrima (Beurl.) Standl., Contr. Arnold Arbor. 5:55. 1933. [misapplied]

Trema domingensis Urb , Symb. Antill. (Urban) 7(2):191. 1912. (as domingense). TYPE: DOMINICAN REPUBLIC: Sto. Domingo australi propre Barahona, Apr 1910, M. Fuertes 312, in part [B, NY( $\times 2$ ), U, USD]. (LeCtotype, here designated: B [100247958] internet image!; ISOLECTOTYPES, here designated: NY [00025180]! and [00025179]!, U [0044459] image provided!, USD [00000069] image provided!). [Non M. Fuertes 312, in part (G, P, US, Z), = Celtis trinervia Lam., Encycl. 4:140. 1797].

Trema laxiflora Lundell, Wrightia 2(2):50. 1960. Type: GUATEMALA. Petén: San Luis-Poptun Rd., in secondary forest, 9 Jul 1959, C.L. Lundell 19260 (ноLотуPE: TEX-LL [LL00370454] internet image!); IsotyPEs: TEX-LL [LL00370453] internet image!, S [S-R-6173] internet image!). Paratypes: GUATEMALA. Petén: km 56 of road, 10 Jul 1959, Lundell 16311 (MEXU [518408] internet image!, MO [3832216]!, TEX-LL [not seen]).

TAXONOMIC DESCRIPTION OF TREMA DOMINGENSIS URB. S.L.

Tree, to $35 \mathrm{~m}$ tall and $60 \mathrm{~cm}$ diam., but typically 20-30 cm dbh, rarely shrubby. Trunk straight, cylindrical; leaves and branches spirally arranged on trunk, distichous on lateral branches; lateral branches relatively thin, sparsely branched, initially ascending, becoming perpendicular with age then pendent before falling off. Stilt roots or short buttresses to $50 \mathrm{~cm}$ tall sometimes present on larger individuals (Little \& Dixon 1969; Pennington et al. 2004). Wood soft, sapwood thin, whitish, heartwood yellowish brown to beige (Little \& Dixon 1969). Outer bark on trunk initially greenish grey or whitish, smooth, becoming darker and rough with many warty lenticels with age (Little \& Dixon 1969; Pennington et al. 2004); branch scars persisting on trunks up to at least $20 \mathrm{~cm} \mathrm{dbh}$. Inner bark fibrous and bitter, surface tan to reddish, interior tan to pinkish or redveined (Little \& Dixon 1969).

Branches terete except for low ridges descending down internode on both sides of petioles; internodes typically $1.5-6 \mathrm{~cm}$ long, with solid pith; surface smooth, green and pubescent, becoming greyish, \pm glabrous and lenticellate in age; appressed whitish hairs $0.1-0.3 \mathrm{~mm}$ long, conspicuous on young branches but not persisting; dense very minute erect hairs $<0.1 \mathrm{~mm}$ long persisting until epidermis shed. Terminal buds covered by stipules and young densely pubescent conduplicate leaves. Stipules free, lateral to petioles, lanceolate, 1.5-4.0 $\mathrm{mm}$ long, $0.6-0.8 \mathrm{~mm}$ wide at base, caducous. Leaves largest at base of lateral branches close to trunk, decreasing in mature size toward branch apex; reproductive specimens collected from tips of long branches often preserve smallest mature leaves while sterile specimens from short young branches preserve largest leaves.

Leaves alternate, 2-ranked, petiolate. Petioles typically $0.4-2 \mathrm{~cm}$ long (median: $1.1 \mathrm{~cm}$ ), ratio of petiole 
length to blade length 0.04-0.21 (median: 0.10); slender, grooved adaxially, pulvinus absent; finely pubescent with thin appressed hairs $0.1-0.3 \mathrm{~mm}$ long, sometimes with minute erect hairs $\leq 0.1 \mathrm{~mm}$ tall adaxially. Blades 5-20 cm long (median: $11.1 \mathrm{~cm}$ ), 2-9 cm wide (median: $4.0 \mathrm{~cm}$ ), ovate to narrowly lanceolate or rarely elliptic, larger and more ovate at base of branch, smaller and more narrowly lanceolate to elliptic at tips of longer branches, ratio of blade width to length $0.24-0.53$ (median: 0.36), ratio of distance from base to widest part to blade length 0.17-0.48 (median: 0.28); base rounded, subcordate, subtruncate, or acute, rarely \pm oblique (Brand 323); apex acuminate to long-acuminate, rarely acute, $0-4 \mathrm{~cm}$ long (median: $1.7 \mathrm{~cm}$ ), ratio of apex length to blade length 0.06-0.34 (median: 0.16); margin entire in adults, rarely with a few minute teeth (Neill 7466), but conspicuously toothed in juveniles (Salick 8089), flat or \pm revolute; lamina thin, green to yellowish green and \pm shiny above, paler matte green below when fresh; drying olive-green and \pm shiny above and yellow-green below, contrasting veins more yellowish or brownish. Upper (adaxial) surface of blade smooth when fresh to slightly scabrous when dry, warty when dry from abundant conspicuous circular cystoliths mostly ca. $0.1 \mathrm{~mm}$ diam., largest cystoliths with short sharp recurved hairs ca $0.1 \mathrm{~mm}$ long, smallest with longer caducous thin white appressed hairs $0.2-0.3 \mathrm{~mm}$ long; hairs on primary and secondary veins sparse, appressed, $0.2-0.4 \mathrm{~mm}$ long, ephemeral brown glandular hairs $\leq 0.1 \mathrm{~mm}$ long sometimes present (e.g., Hayden 4, Timana 3227, Irwin 54824). Lower (abaxial) surface of blade smooth when fresh to very slightly scabrous when dry, usually densely finely pubescent (but easily overlooked with a hand-lens), not glabrous in age as sometimes reported; hairs clear to white, thin, appressed, persistent, mostly $0.1-0.2 \mathrm{~mm}$ long, aligned in one direction toward margin or apex, with bases sometimes enlarged (to ca. $0.05 \mathrm{~mm}$ diam.) but only rarely approaching size of cystoliths on upper surface (Brand 337; Garwood 5-10 and 5-11); hairs on primary and secondary veins appressed toward apex, longer than on blades, mostly $0.1-0.3 \mathrm{~mm}$ long (rarely to $0.5 \mathrm{~mm}$ ). Venation 3-nerved at the base, pinnately nerved distally; typically 3-5 arching secondary veins per side, converging toward apex but only most apical vein on each side reaching into apex; tertiary veins widely spaced between midrib and secondary veins (2-5 mm apart), \pm scalariform; higher order veins anastomosing, forming small \pm rectangular cells ca. $0.5 \mathrm{~mm}$ wide. When fresh or dry, primary and secondary veins slightly impressed into blade on upper surface, tertiary and higher order veins above immersed in the blade; primary and secondary veins prominently raised above blade on lower surface, tertiary veins slightly raised, higher order veins immersed in blade.

Plants monoecious, possibly sometimes dioecious; flowers unisexual. Inflorescences axillary thyrsoid cymes, usually 2 per axil (with a vegetative bud between them), initiated at tips of growing lateral branches, each typically to $2 \mathrm{~cm}$ tall and $2 \mathrm{~cm}$ wide at anthesis, up to or slightly exceeding the petioles in length, to $3 \mathrm{~cm}$ tall by $4 \mathrm{~cm}$ wide in fruit; up to 60 flowers per cyme, with up to 20 fruits maturing per cyme; peduncles 1.5-5 mm long; branches within cymes 1-5 mm long; peduncles and branches green when fresh, with appressed to ascending hairs $0.1-0.3 \mathrm{~mm}$ long, persistent very minute erect hairs $\leq 0.1 \mathrm{~mm}$ long, and sometimes ephemeral brown glandular hairs $\leq 0.1 \mathrm{~mm}$ long (e.g., Meneces 471, Timana 3227, Stevenson 894). Bracts within cymes 0.6-1.2 mm long, pale green when fresh, with appressed hairs. Within each cyme, flower buds initially congested (glomerate), but flowers becoming more widely spaced (laxiflorous) by anthesis; carpellate and staminate flowers often intermixed, usually staminate flowers most abundant, sometimes inflorescences either all carpellate or all staminate; when cymes intermixed, flowering protogynous and fruit enlarging before staminate flowers reach anthesis.

Staminate flowers $1.3-1.5 \mathrm{~mm}$ in diameter in mature bud, to $2.2 \mathrm{~mm}$ in diameter at anthesis, falling soon after anthesis. Pedicels $0-0.3 \mathrm{~mm}$ long. Receptacle scarcely developed. Tepals 5, pale green, each 1.1-1.4 mm long, 0.5-0.6 mm wide, elliptic to ovate in outline, strongly concave, induplicate-valvate; margins ciliate, especially at apex, with fine hairs $0.1-0.15 \mathrm{~mm}$ long; outer surface warty from enlarged bases of appressed thicker hairs 0.1-0.15 mm long. Stamens 5, opposite to and cupped within tepals before and just after opening, with filaments adjacent to tepals and anthers surrounding carpellode; filaments then extending and pushing anthers beyond tepals. Filaments inflexed in bud, as long as tepals when fully extended, \pm flattened, white to pale green, glabrous. Anthers $0.5-0.8 \mathrm{~mm}$ long, subglobose, white to cream-colored, opening by longitudinal slits; pollen white when fresh, drying yellow to orange. Carpellode $\leq 1 \mathrm{~mm}$ long, subcylindrical to obovoid, 
pubescent at apex with erect minute hairs, pale green to cream-colored, with dense ring of long white erect hairs (0.4-0.5 mm tall) surrounding base.

Carpellate flowers ca. $2 \mathrm{~mm}$ long and $1 \mathrm{~mm}$ wide at anthesis. Pedicels initially $0.1-0.2 \mathrm{~mm}$ long, to 0.3 $\mathrm{mm}$ when fruits mature, jointed at apex; glabrous. Receptacle green, more than twice as wide as the pedicel apically, 0.3-0.4 mm long, with minute appressed hairs. Tepals 5, green, becoming yellowish-green and persisting below mature fruit, outer surface somewhat warty from enlarged bases of appressed thicker hairs (0.1-0.15 mm long), each 0.6-1 mm long, \pm triangular, scarcely reaching half the length of ovary, dimorphic; outer tepals 2, each 0.3-0.5 mm wide, without wings; inner tepals 3, each 0.5-0.8 mm wide, flattened and closely appressed to ovary, with membranous minutely fimbriate wings. Staminodes absent. Ovary ovoid to ellipsoid, green, $0.8-1.1 \mathrm{~mm}$ long when receptive; glabrous or with a few hairs apically, with dense ring of long white erect hairs $(0.4-0.5 \mathrm{~mm}$ tall) surrounding base but obscured by tepals. Stigmas 2 , sessile, initially erect and appressed, 0.9-1.2 mm long, becoming whitish and recurved when receptive, then brown and shriveled after fruit set; inner surface papillate.

Fruit drupes, globose to ovoid, 2.5-3.0 mm long, 2-2.5 mm wide, short-apiculate from remains of stigma, green when immature, typically ripening pale pink to pale orangish pink (sometimes reported as orange or red). Exocarp thin; mesocarp \pm fleshy; endocarp thick, stony, 1.6-2.0 mm long and 1.6-2.0 mm wide, slightly compressed, slightly sculptured, dark brown to black. Seed with thin seed coat, copious endosperm, curved embryo.

Seedlings phanerocotylar, epigeal. Hypocotyl 10-20 mm long, green; epicotyl 2-5 mm long, green. Cotyledons 2, foliaceous, elliptic, $10-16 \mathrm{~mm}$ long, 5-8 mm wide, with rounded base and apex. Leaves at first node opposite, 20-35 mm long, 12-17 mm wide, ovate to lanceolate, with two or three teeth per side in the apical half. Later leaves alternate, toothed. Older juveniles similar to adults except leaves are toothed.

Habitat.-Trema domingensis is a tree of wet lowland evergreen forests, mostly 0-1000 m, rarely to 1500 $\mathrm{m}$. It is a fast-growing pioneer, colonizing tree-fall gaps or roadsides through dense forest. In a permanent 50 ha plot in the Ecuadorian Amazon, it is short-lived, rarely persisting for more than 10 years, and rare in primary forest, with only 4 to 18 individuals $\geq 1 \mathrm{~cm}$ dbh present in 25 ha in three censuses over a $15 \mathrm{yr}$ period (R. Valencia, pers. comm.). The species reaches its largest size ( $35 \mathrm{~m}$ and $60 \mathrm{~cm} \mathrm{dbh)} \mathrm{in} \mathrm{Ecuador} \mathrm{(Little} \mathrm{1948,} \mathrm{Little}$ \& Dixon 1969, Legaard \& Balsev 2014) and Peru (Pennington et al. 2004), especially on deep alluvial soils such as those at Rio Palenque Science Center (Garwood, pers. obs.). Ecologists have been slow to recognize the species in the field because juveniles encountered have toothed, not entire, leaves and are mistaken for $T$. micrantha. The soft wood is a potential source for paper pulp and is used for house construction in Peru (Lewis 11786); the fibrous bark is sometimes woven into ropes (Little \& Dixon 1969; Neill 7466).

Reproductive Biology.-The reproductive biology of T. domingensis is poorly known. Observations from herbarium specimens and field work at Estación Científica Yasuní (ECY), Orellana Province, Ecuador, indicate that inflorescences develop at the tips of the growing lateral branches. Cymes are densely glomerate in the axils of the youngest leaves, but expand and become more open at older nodes as anthesis approaches. In cymes with both sexes, flowering is protogynous. Receptive carpellate flowers, with fresh stigmas, open in the most distal inflorescences, while fruits mature sequentially in more proximal cymes. Staminate flowers reach anthesis only in cymes with young developing fruit, not in cymes with receptive carpellate flowers. By the time fruits reach maturity at older nodes, all staminate flowers have fallen. The longest lateral branches may have ripe fruit on nodes nearest the trunk, and flowers in anthesis at the branch tip.

The species is reported as monoecious, or monoecious and/or dioecious. Although herbarium specimens sample only a single branch of the tree at one point in time, they allow a broad examination of the breeding system through the range of the species. We categorized the reproductive state of all specimens cited as sterile, flowering (staminate only, carpellate only, or monoecious), or fruiting (with immature or mature fruit but without flowers). No bisexual flowers were seen. Of the 46 herbarium specimens examined and cited below, 11 (24\%) were sterile (1-10 m tall). Of the 35 reproductive specimens (4-34 $\mathrm{m}$ tall), nine (26\%) were monoecious, five (14\%) had only carpellate flowers, four (11\%) had only staminate flowers, 14 (40\%) had only fruit, and two 
(images) could not be determined. Cymes on monecious specimens were heavily male-biased (carpellate flowers in cymes ranged from 0-23\% of all flowers, median: $4 \%$ ). Monoecy is likely underrepresented, as specimens with nearly mature fruit have probably lost their male flowers by this stage. Of those with only carpellate flowers, two specimens (Timana 3227, Irwin 54824) stand out because carpellate flowers were very abundant, in contrast to specimens with mixed cymes, where carpellate flowers were few. Three of the four specimens with only staminate flowers had only a few several-flowered cymes, but the other (Brand 323) had many well-developed staminate-flowered cymes along the branch.

At the population level, we examined 29 specimens collected at Yasuní, Ecuador. This includes 12 specimens cited below and 17 specimens examined at the field herbarium at ECY: Perez 4109, Perez 3686, Anon. s.n. (tree tag 33663) Anon. s.n. (tree tag 243399), and SSP 6704, SSP 6708 to SSP 6716, and SSP 6744 to SSP 6746 (SSP=Seed and Seedling Project, PI: Garwood). Six individuals (21\%) were sterile (1-9 m tall). Of the 23 fertile specimens (8-20 m tall), 14 (61\%) were monoecious, eight (35\%) bore only developing or mature fruits, and one (4\%) had only female flowers. The latter was a small individual ( $8 \mathrm{~m}$ tall), with only a few flowers on several small cymes. Cymes on monoecious specimens were typically male dominated, but less so than in the herbarium sample (carpellate flowers in cymes ranged from 0-100\% of all flowers, median: $27 \%$ ). Of two individuals studied intensely for 2 weeks (May 2016), one tree produced only carpellate flowers, the other both staminate and carpellate flowers. Whether some individuals are truly dioecious throughout their lifespan is still unknown, but there is clearly considerable flexibility in sex expression in this species. The only quantitative study of sexual expression in populations of Trema, of T. micrantha in Brazil (Torres 1996), found that ca. $60 \%$ of all individuals were female throughout the reproductive season, $36 \%$ began as males but became female or monecious during the season, and the remainder were mostly male or female with the occasional flower of the opposite sex or bisexual flower. Not surprisingly, out-crossing was common in those Brazilian populations (Ribas \& Kageyama 2006). Variation in sexual expression may be common in Cannabaceae (Yang et al. 2013) and other Rosales, such as Morus (Nepal et al. 2015).

Phenology.-Trees flower and fruit for long periods, but are not fertile continuously throughout the year at Yasuní, Ecuador (Garwood, pers. obs.). At Yasuní, flowering specimens were collected May-July and November, and those with mature fruits in July and February. Of herbarium specimens examined, those from Central America had flowers and/or fruits April-November, those from the Caribbean April-July, and those from South America June-March.

Range.-The species occurs in the Caribbean (Dominican Republic, St. Vincent, Martinique), Central America (Mexico to Panama), and South America (Venezuela to Bolivia, Guyana, Suriname and Brazil). Representative specimens are cited below.

Other specimens examined (*: unmounted specimens in Garwood's collection, held at SIU, to be deposited at F at the end of the study. \$: specimens included in leaf morphometric analysis): BELIZE. Toledo: BFREE Reserve, Bladen River bank, 45-75 m, 23 Oct 2005, Whitefoord E Quiroz 106231 (MO¥); BFREE, near Bladen Reserve, ca. 50 m, 23 Oct 2005, Garwood 231 (*); near Pueblo Viejo, ca. 350 m, 28 Feb 2005 , Garwood 5-5, 5-10, and 5-11 (*⿻, all). BOLIVIA. La Paz: Franz Tamayo, Parque Nacional y Área Natural de Manejo Integrado Madidi, Chalalan, Sendero Paraba, 370 m, 25 Nov 2004, Araujo-M et al. 1112 (MO¥). Santa Cruz: Reserva Forestal "El Chore”, 65 km norte de

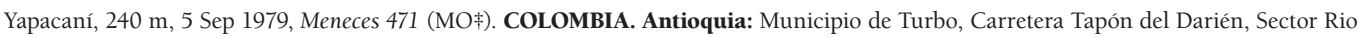
Leon-Lomas Aisladas, km 37, 60 m, 27 Jun 1983, Brand \& Ascanio 337 (MO¥); Urabá-Chigorodó-Malagón, Caño Malagón, 10 m, 22 Mar 1986, Renteria 4696 (MO); Municipio de Mutatá, camino de Bajirá hacia los Cedros, 1 km, 75 m, 21 Mar 1983, Brand E Ascanio 323 (MO丰. Meta: Parque Nacional Natural Tinigua, Serranía Cahmusa, Centro de Investigaciones Perinatológicas La Macarena, 350 m, Feb 1994, Stevenson 894 (MO). COSTA RICA. Guanacaste: Tilarán, Cuenca de San Carolos, Arenal, 600 m, 20 Aug 2003, Solano 258 (MO). Heredia: La Selva Biological Station, ca 65 m, 31 Dec 2001, Dalling \& Huertos s.n. (*). San José: Cantón de Mora, Camino entre Ciudad Colón y El Rodeo, 650 m, 23 Sep 1996, Cascante 1184 (MO $)$ ); Puriscal, slopes of Cerro Tufares along Route 239, 880 m, 23 Jul 1988, Grayum et al. 8654 (BM‡; MEXU, internet image). DOMINICAN REPUBLIC. Duarte: Cordillera Septentrional, Loma Quita-Espuela, 400 m, 25 Apr 1929 , Ekman 12293 (S $¥ 04-933$, U 034891, US 00835256: internet images [S, US], provided image [U, K], leaf fragment [S]). El Seibo (as Seybo): Codillera Central, El Jobero, road to Seybo, 19 Jul 1230, Ekman 15720 (S¥ 15-27092, US 00835257, K s. n.: internet images [S, US], provided imaged [K,], leaf fragment [S]). ECUADOR. Esmeraldas: Anchayacu, Eloy Alfar, Mayronga, 100-250 m, 24 Oct 1993, Pennington et al. 14365 (MO¥). Morona-Santiago: Bomboiza, colinas arriba de la Misión Salesiana - Shuar, 800-1000 m, 6 Nov 1986, Neill \& Cerón 7466 (MO¥). Orellana: Parque Nacional Yasuní, Estación Científica Yasuní [within 30 min. walking distance of the station], ca 250 m, 1-10 Jul 2001, Garwood et al. 4514, 4516, 4540, 4541, 4542, 4543, 4544, 4545, 4546 4556, 4557, 4562 (* ${ }^{*}$ all 12). Pichincha: low elevation lowlands west of the 
Andes, 11 July 2001, Garwood et al. 4575 (*キ). Los Rios: Estación Biológica Río Palenque, km 56 Quevedo-Santo Domingo (Ecuador 25), 175 m, 7 Jun 2003, Villa et al. 2051 \& $20622^{*}$ ). Sucumbios: Carreterra Nueva Loja a Pompeya, km 83 desde el Rio Aquarico, 200-300 m, 14 mar 2003, Villa \& Garwood $2144{ }^{*}$ ). GUATEMALA. Peten: San Luis, km 56 of road, 10 Jul 1959, Lundell 16311 (Paratype of T. laxiflora: MO¥; MEXU, internet image); San Luis-Poptun Road, 9 Jul 1959, Lundell 16260 (Holotype of T. laxiflora: TEX-LL丰, internet image; isotypes: S \& TEX-LL, internet images). HONDURAS. Atlántida: Lancetilla Valley, near Tela, 20-600 m, 6 Dec 1927 to 20 Mar 1928, Standley 54097 (Fł 582173, provided image; US 01926462: internet image). MARTINIQUE: 8 Nov 1881, Duss 1 (P市, MNHN-P-P06885119, internet image). MEXICO. Chiapas: Mpio. Ocosingo, sobre el Rio Lacantun, 150 m, 7 Sep 1992, Martinez et al. 25233 (MEXU, internet image); Mpio. Ocosingo, Estación Biológica Chajul, 300 m, 12 Jun 1992, Vázquez 450 (MEXU, internet image, as T. micrantha var. strigillosa). NICARAGUA. Rio San Juan: Municipio de el Castillo, entre la Estación Biológica La Lupe y el Caserio el km 20, 200 m, 29 Oct 1997, Rueda et al. 7543 (MO¥); Marcelo, near Rio Sabalos, 7 Oct 1991, Salick 8089 (MO (US $¥ 019266461$ : internet image); Changuinola Valley, along river, 19 Feb 1924, Dunlap 442 (F). Panama: northern suburbs of Panama City, about $3.8 \mathrm{~km}$ due $\mathrm{N}$ of intersection of Panama routes 6 and 3, ca $67 \mathrm{~m}, 5 \mathrm{Jul}$ 2016, Bernal 670, 671, 672, 673 ( ${ }^{*}$, all four). Panamá Oeste: Barro Colorado Island, near ZMA House, Jun 1965, Hayden 4 (MO¥); Barro Colorado Island, 1931, Aviles 58a (MO¥, internet image); Barro Colorado Island, 50 ha plot, 120 m, 14 Jul 2009, Perez 2293 (SCZ m, 13-16 Nov 1986, Lewis et al. 11786 (MO ). Madre de Dios: Tambopata, Las Piedras, Cusco Amazónico, Inventario Permanente, 200 m, 16 Nov 1991, Timaná \& Jaramillo 3227 (MOキ); Explorer’s Inn, near confluence of Rio Tambopata and Rio La Torre, 39 km SW of Puerto Moldonado, 21 Jan 1989, Smith et al. 1471 (MOキ). ST. VINCENT \& THE GRENADINES. St. Vincent: Mar 1890, H.H. Smith \& G.W. Smith 70 (BMキ). SURINAME. Sipaliwini: Wilhelmina Gebergte, lower slopes of Juliana Top, 15 km N of Lucie River, $600 \mathrm{~m}, 16$ Aug 1963 , Irwin et al. 54824 (MO ). VENEZUELA. Zulia: Distrito Perijá, hills bordering Quebrada Cosira, $3.5 \mathrm{~km} \mathrm{SW}$ of Los Angeles de Tucuco, foothills of Cerro Cunasamo, 200-460 m, 24 Jun 1980, Davidse et al. 18551 (MO丰).

\section{APPENDIX}

Specimens measured for the morphometric analysis. ${ }^{*}=$ unmounted specimens in Garwood's collection, held at SIU, to be deposited at $\mathrm{F}$ at the end of the study.

Trema cubensis: Cuba: Ekman 9261 (NY, type); Dominican Republic: Zanoni 19285 (NY), Zanoni 25832 (NY), Zanoni 33967 (NY), Zanoni 34002 (NY), Zanoni 40263 (NY), Zanoni 41464 (NY).

Trema lamarckiana: Bahamas: Shallert 2140 (FLAS), Van Eenwyk 4-109a (FLAS), Wunderlin 8253 (MO); Cuba: DeChamps 49688 (MO), Gentry 50938 (MO); Gentry 51023 (MO); Cayman Islands: Brunt 2049 (BM); Dominica: Ernst 1965 (BM); Dominican Republic: Howard 12093 (BM), Wise X87 (NY), Zanoni 13516 (NY), Zanoni 15344 (NY), Zanoni 22994 (NY), Zanoni 31898 (NY), Zanoni 31901 (NY), Zanoni 31924 (NY), Zanoni 31928 (NY), Zanoni 40107 (NY); Haiti: Thompson 4105 (FLAS); Jamaica: Harris 6508 (US), Hart 579 (US), Proctor 23226 (NY), Proctor 36513 (MO), Proctor 7406 (US), Purdie s.n. (TCD), Robbins 1675 (NY), Webster 4990 (US); Montserrat: Howard 18957 (BM); Puerto Rico: Axelrod 8130 (MO), Judd 6089 (FLAS), Taylor 10514 (MO); USA, Florida: Avery 905 (FLAS), Craighead 443 (FLAS), Craighead s.n. (FLAS), Koop $5\left(^{*}\right)$, Koop $12(*)$, O’Neill s.n. (FLAS).

Trema micrantha (all clades): Argentina: Deginani 1040 (MO), Meyers 4957 (BM), Renvoize 3269 (FLAS); Belize: Garwood B04 $\left(^{*}\right)$, Garwood B06 $\left(^{*}\right)$, Garwood B09 $\left(^{*}\right)$, Garwood B14 $\left(^{*}\right)$, Garwood B17 $\left(^{*}\right)$, Garwood B19 $\left(^{*}\right)$, Garwood B20 $\left(^{*}\right)$, Garwood B23 $\left(^{*}\right)$, Garwood B25 $(*)$, Garwood B28 (*), Garwood B30 (*); Bolivia: Arroyo 4116 (MO), Fuentes 9304 (MO), Lewis 40551 (MO), Nee 51812 (MO), Nee 53226 (MO), Quevedo 2445 (FLAS); Brazil: Agra 5007 (MO), Amaral 1141 (MO), Amorim 1239 (MO), Anderson 10136 (NY), Anderson 36289 (NY), Conceicao 442 (NY), dos Santos 3501 (NY), Dusen s.n. (NY), Gadelha 3484 (NY), Irwin 21610 (NY), Irwin 24178 (NY), Irwin 34910 (NY), Lasseign P21199 (NY), Philcox 4028 (NY), Prance 19244 (FLAS), Thomas 11471 (NY), Thomas MT588 (FLAS), Todzia 2231 (MO); British Virgin Islands: Little 26124 (NY); Colombia: Forero 2 (MO), Gentry 18152 (FLAS), Giraldo-Canas 244 (MO); Cuba: Ferandez Casas 10596 (MO); Dominica: Whitefoord 4426(BM); Dominican Republic: Basilio Augusto 1078 (NY), Carter 5112 (MO), Liogier 15415 (NY), Mejia 353 (MO), Mejia 6855 (NY), Mejia 14768 (MO), Mejia 23545 (MO), Zanoni 16685 (MO), Zanoni 19282 (MO), Zanoni 21733 (NY), Zanoni 25830 (MO), Zanoni 26547 (NY), Zanoni 30410 (NY), Zanoni 37078 (NY), Zanoni 40486 (NY); Ecuador: Garwood 4525 (*), Garwood 4547 $(*)$, Garwood $4548\left(^{*}\right)$, Garwood $\left.45522^{*}\right)$, Garwood $\left.45533^{*}\right)$, Garwood $4554\left(^{*}\right)$, Garwood $4558\left(^{*}\right)$, Garwood $4559\left(^{*}\right)$, Garwood $4560\left(^{*}\right)$, Garwood 4561 (*), Narvaez 428 (MO), Palacio 2177 (MO), Quizhpe 2799 (MO); French Guiana: Croat 102471 (MO); Guatemala: Popenoe 49 (FLAS), Snedaker D-62 (FLAS); Guyana: Boom 7324 (MO), Jansen-Jacobs 658 (MO); Honduras: Williams 17399 (BM); Jamaica: Adams 11328 (UCWI), Anderson 3005 (US), Britton 3617 (NY), Crosby 225 (US), Harris 9885 (US), Hartweg 1569 (US), Howard 14003 (US), Jam. PI. 1382 (UCWI), Jam. PI. 1439 (UCWI), Kapos 1559 (MO), Proctor 19795 (US), Proctor 23831 (US), Proctor 9839 (NY), Purdie s.n. (TCD); Mexico: Abbott 19812 (FLAS), Dressler 236 (BM), Mendez 395 (FLAS), Nee 25106 (BM); Narvassa Island: Buck 34377 (NY); Nicaragua: Mark 6425 (FLAS); Panama: Dalling $2\left(^{*}\right)$, Dalling $3\left(^{*}\right)$, Dalling $4\left(^{*}\right)$, Dalling $6\left(^{*}\right)$, Dalling $11\left(^{*}\right)$, Dalling $15\left(^{*}\right)$, Dalling $39\left(^{*}\right)$, Dalling 45 $\left(^{*}\right)$, Dalling $48\left(^{*}\right)$, Dalling $51\left(^{*}\right)$, Dalling $55\left(^{*}\right)$, Dalling $59\left(^{*}\right)$, Dalling $61\left(^{*}\right)$, Dalling $62\left(^{*}\right)$, Dalling $63\left(^{*}\right)$, Dalling $65\left(^{*}\right)$, Dalling $74\left(^{*}\right)$, Dalling $78\left(^{*}\right)$, Dalling $80(*)$, Dalling $83\left(^{*}\right)$, Dalling $84\left(^{*}\right)$, Dalling $85\left(^{*}\right)$; Paraguay: Benitez $579(\mathrm{MO})$, Hahn 2307 (MO); Peru: Galiano 4462 (MO), Huamantupa 9562 (MO), Perea 3899 (MO), Rimachi 2449 (FLAS), Sagastegui 8326 (FLAS), Sucilli 2152 (MO), Valenzuela 364 (MO); Puerto Rico: Little 13046 (NY), Nee 44139 (NY), Stimson 3009 (FLAS), Sustache s.n. (*), Taylor 10129 (MO), Vincent 15484 (UPRRP); Suriname: Croat 102457 (MO); Swan Islands: Proctor 32504 (BM); Trinidad \& Tobago: Worthington 18155 (MO); USA, Florida: Abbott 24973 (FLAS), Abbott 25239 (FLAS), Bodle s.n. (FLAS), Koop $1\left(^{*}\right)$, Koop $2\left(^{*}\right)$, Koop $3(*)$, Koop $4(*)$, Koop $6\left(^{*}\right)$, Koop $7(*)$, Koop $8\left(^{*}\right)$, Koop 9 $\left({ }^{*}\right)$, Koop $10(*)$, Koop $11\left(^{*}\right)$, Koop $13(*)$, Koop $14\left(^{*}\right)$, Koop $15\left(^{*}\right)$, Little 15015 (FLAS), Little 16508 (FLAS), McDaniel 9166 (FLAS), Scull s.n. (FLAS), Small 11626 (FLAS), Stern 2822 (FLAS), West \& Louck s.n. (FLAS), Wunderlin 8857 (FLAS); US Virgin Islands: Acevedo 619 (NY), Acevedo-Rodriguez 3841 (MO), Mori 17017 (BM); Venezuela: Cornelius 906 (FLAS), Davidse 4089 (MO), Diaz 493 (MO), Knab-Vispo 538 (MO), Manara s.n. (MO), Stergios 2948 (MO), Stergios 5110 (MO), Stergios 5925 (FLAS). 


\section{ACKNOWLEDGMENTS}

We thank the curators at the following herbaria for loans of specimens for molecular and morphological analysis: S, NY, MO, FLAS, BM, DAO, E and UPRRP. We also thank staff at F, S, US, USD, K, U, and MO for scanning specimens not already imaged and making them available to us for this study; librarians at MO and SIU and the Biodiversity Heritage Library for supplying needed references; Johannes Lundberg (S) for reviewing historic specimens of Pouzolzia at S; Karolina Jerrå for bringing Ekman 15720 at K \& S to our attention; Renato Valencia (P.U.C.E.) for sharing data from the Yasuní, Ecuador, forest dynamics plot; Nina Kirit Karia and Ester Barney (funded by an UK Nuffield Science Bursary in 2001) and the SIU plant systematics classes of 2016 \& 2017 for measuring Trema leaves; and Milton Zambrano and Pablo Alvia for photographing Trema in Yasuní. DNA data and SEM images were primarily made possible by start up funds to KMN, from a REACH scholarship from SIU to KJ, an NSF REU (DEB-1122634) to NCG for KJ and lab funds at NHM for AMH and SJR. Janice Valencia aided in the Spanish abstract and two anonymous reviewers made helpful comments on the manuscript. Lucas Majure, Walter Judd, Melanie Schori, Barney Lipscomb, Peter Fritsch, and Kanchi Gandhi assisted in the nomenclatural decisions on this manuscript.

\section{DATA ACCESSIBILITY}

Data and supplemental figures are available from the Dryad Digital Repository: doi:10.5061/dryad.j447ch4 (Garwood et al. 2018). Supplemental figures: Figure S1. Effect of removing tooth density from the full leaf morphometric analysis. Figure S2. Component loadings for the full analysis (seven variables, three leaves per specimen). Figure S3. Effect of using the average or largest leaf measurement per specimen.

\section{REFERENCES}

Аввотт, J.R. 2009. Phylogeny of the Polygalaceae and a revision of Badiera. PhD dissertation. University of Florida, Gainesville, U.S.A. http://etd.fcla.edu/UF/UFE0041138/abbott_j.pdf

Acevedo-Rodríguez, P. \& M.T. Strong. 2012. Cannabaceae. Catalogue of seed plants of the West Indies. Smithsonian Institution Scholarly Press, Washington D.C., U.S.A. Pp. 207-208.

Anon. 1856. P.J. Beuerling, Primitiae Florae Portobellenis. Z. Gesammten Naturwiss. (Halle) 8:265-266.

Anon. (Rolfe, R.A.). 1893. Urticaceae. Flora of St. Vincent and adjacent islets. Bull. Misc. Inform., Kew. 81. Pp. 276. (Attributed to R.A. Rolfe, in Anon. 1893, Book-Notes, News \&c. J. Bot. 31:351, J. Britten, ed.

Balick, M.J., M.H. Nee, \& D.E. Atha. 2000. Ulmaceae. Checklist of the vascular plants of Belize. Mem. New York Bot. Gard. 85:56.

BerG, C.C. 1992. Trema. In: A.R.A. Gorts-van Rijn, ed. Flora of the Guianas, Series A, Phanerogams, Fascicle 11:6-9. Koelz Scientific Books, Koenigstein, FRG.

BerG, C.C. 1997. Ulmaceae. In: J. Boggan, V. Funk, C. Kelloff, M. Hoff, G. Cremers, \& C. Feuillet, eds. Checklist of the plants of the Guianas (Guyana, Surinam, French Guiana). $2^{\text {nd }}$ edition. Centre for the Study of Biological Diversity, University of Guyana, Georgetown, Guyana. Pp. 203-204.

Berg, C.C., P.E. Berry, \& J.S. Miller. 2007. Ulmaceae. In: V. Funk, T. Hollowell, P. Berry, C. Kelloff, \& S.N. Alexander, eds. Checklist of the plants of the Guiana shield. Contr. U.S. Natl. Herb. 55:42.

Bergius Botanic GaRden. (continuously updated). Search for plants in the Bergius Herbarium. www.bergianska.se/english/ collections/the-bergius-herbarium/search-the-collections. Accessed 17 Nov 2017.

Beurling, P.J. 1854 [1856]. Primitiae florae Portobellensis. Kongl. Svenska Vetensk. Acad. Handl., ser. 3, 40:107-148.

Blume, C.L. 1856. Trema. Museum Botanicum Lugduno-Batvaum 2:58-64.

Breugel, M. van, P. van Breugel, P.A. Jansen, M. Martínez-Ramos, \& F. Bongers. 2012. The relative importance of aboveversus belowground competition for tree growth during early succession of a tropical forest. PI. Ecol. 213:25-34. doi:10.1007/s11258-011-0003-3

BURGER, W. 1977. Trema. Flora Costaricensis. Fieldiana 40:90-92.

CARAUTA, J.P.P. 1974. Indice das espécies de Ulmaceae do Brasil. Rodriguésia 27(39):99-134.

CHASE, M.W. \& H.H. Hills. 1991. Silica gel: An ideal material for field preservation of leaf samples for DNA studies. Taxon 40:215-220. doi:10.2307/1222975 
Clark, J.L., D.A. NeILL, \& M. AsanzA. 2006. Ulmaceae. Floristic checklist of the Mache-Chindul Mountians of northwestern Ecuador. Contr. U.S. Natl. Herb. 54:175-176.

Chernomor, O., A. von HaeseleR, \& B.Q. Minh. 2016. Terrace aware data structure for phylogenomic inference from supermatrices. Syst. Biol. 65:997-1008. doi:10.1093/sysbio/syw037

Clayton, J.W, E.S. Fernando, P.S. Soltis, \& D.E. Soltis. 2007. Molecular phylogeny of the tree-of-heaven family (Simaroubaceae) based on chloroplast and nuclear markers. Int. J. PI. Sci. 168:1325-1339. doi:10.1086/521796

Correa A., M.D., C. Galdames, \& M. Stapf. 2004. Ulmaceae. Catálogo de las plantas vasculares de Panamá. Universidad de Panama y Instituto Smithsonian de Investigaciones Tropicales, Panamá. Pp. 492.

CroAt, T.B. 1978. Trema. Flora of Barro Colorado Island. Stanford University Press, Stanford, California, U.S.A. Pp. $341-342$.

D'ARCY, W.G. 1987. Trema integerrima. Flora of Panama checklist and index. Part II: Index. Monogr. Syst. Bot. Missouri Bot. Gard. 17. Pg. 631. Trema: www.tropicos.org/Name/40016530?projectid=4. Accessed 19 Feb 2018.

DeCAISNE, M.J. 1834. Sponia. Description d'un herbier de l'ile de Timor. Novelles annales du Museum d'histoire naturelle 3:498-499.

Dodson, C.H. \& A.H. Gentry. 1978. Ulmaceae. Flora of the Río Palenque Science Center: Los Ríos Province, Ecuador. Selbyana 4(1-6):564-566.

DoYLE, J.J \& J.L. DoYLE. 1987. A rapid DNA isolation procedure for small quantities of fresh leaf tissue. Phytochem. Bull. Bot. Soc. Amer. 19:11-15. doi:10.2307/1221122

Duss, R.P. 1897. Urticées. Flore phanérogamique des Antilles francaise (Martinique et Guadeloupe). Extrait des Annales de I'Institute Colonial de Marseille 3(4):152-164. www.manioc.org/patrimon/SCH13269

DWyeR, J.D. \& D.L. SPELLmAn 1981. Ulmaceae. A list of the Dicotyledoneae of Belize. Rhodora 83:233.

Foster, R.C. 1958. Ulmaceae. A catalogue of the ferns and flowering plants of Bolivia. Contr. Gray Herb. 184:65.

Fuertes LoREn, M.D. 1978. Catálogo de plantas colectadas por el Padre Fuertes (Facsímil). Museo del Hombre Dominicano, Academia de Ciencias de la República Dominicana, Santo Domingo. [Hand-written list attributed to Fuertes, but not in his hand fide Liogier 1978]

García, R., M. Mejía, B. Peguero, \& F. Jiménez. 2001. Flora endémica de la Sierra de Bahoruco, Republica Dominicana. Moscosoa 12:9-44.

GARwood, N.C. 2016. Revisiting the lectotype of Rhamnus micranthus (Rhamnaceae). Phytotaxa 284(4):293-295. doi:10.11646/phytotaxa.284.4.6

Garwood, N.C., K. Jordan, N.D. Flowers, A.M. Humphreys, S.J. Russell, \& K.M. Neubig. 2018. Data from: Trema domingensis rises like a mythological phoenix from the ashes of Trema integerrima: a reassessment of the entire-leaved species of Neotropical Trema (Cannabaceae). Dryad Digital Repository. doi:10.5061/dryad.j447ch4

Gaudichaud-Beaupré, C. 1826 [1830]. Pouzolzia. In: L.C.D. de Freycinet, ed. Voy. Uranie, Bot:503.

GBIF [Global Biodiversity Information Facility]. 2017. GBIF Secretariat, GBIF Backbone Taxonomy. Checklist Dataset. doi:10.15468/39omei. Accessed via GBIF.org 17 Feb 2018.

GBIF. 2017a. Trema integerrima. In: GBIF Backbone Taxonomy. www.gbif.org/species/4160101. Accessed 17 Feb 2018.

GBIF. 2017b. Trema domingense. In: GBIF Backbone Taxonomy. www.gbif.org/species/4160257. Accessed 17 Feb 2018.

GBIF. 2017c. Trema laxiflorum .In: GBIF Backbone Taxonomy. www.gbif.org/species/4160033. Accessed 17 Feb 2018.

GARDINER, R.C. 1965. Studies in the leaf anatomy and geographic distribution of western hemisphere Trema. Masters thesis. University of Connecticut, U.S.A.

Grandtner, M.M. 2005. Trema. Elsevier's dictionary of trees. Vol. 1: North America. Elsevier, Amsterdam, Netherlands. Pp. 927-929.

Grandtner, M.M. \& J. Chevrette. 2013. Trema. Elsevier's dictionary of trees. Vol. 2: South America. Elsevier, Amsterdam, Netherlands. Pp. 672.

GrudzinSKAYA, I.A. 1993. Notas sobre el género Trema Lour (Celtidaceae) del nuevo mundo. Bol. Inst. Bot. Univ. Guadalajara $1(7): 465-469$.

HAGER, J. 1990. Flora y vegetación de Loma Quita Espuela: Restos de la vegetación natural en la parte oriental de la Cordillera Septentrional, Republica Dominicana. Moscosoa 6:99-123.

HASSLER, M. 2018. Trema integerrima. In: World Plants: Synonymic checklists of the vascular plants of the world (version Dec 2017). In: Y. Roskov, L. Abucay, T. Orrell, D. Nicolson, N. Bailly, P.M. Kirk, T. Bourgoin, R.E. DeWalt, W. Decock, A. De Wever, E. van Nieukerke, J. Zarucchi, \& L. Penev, eds. Species 2000 \& ITIS Catalogue of Life, 30th January 2018. Digital resource at www.catalogueoflife.org/col. Species 2000: Naturalis, Leiden, the Netherlands. www.catalogueoflife.org/ col/details/species/id/dbaa0ed2c924de0cdfa9435917330044 
HemsLEY, W.B. 1883. Trema. Biologia Centrali-Americana. Botany 3(5):140.

HILL, A.W. 1938. Trema. Index Kew., Supplementum 9:286. Clarendon Press, Oxford, U.K.

HoLST, B.K. \& C.A. TodzIA. 1990. Léon Croizat's plant collections from the Franco-Venezuelan expedition to the headwaters of the Rio Orinoco. Ann. Missouri Bot. Gard. 77:485-516. doi:10.2307/2399514

JACKSON, R.D. 1895. Sponia. Index Kew. 4:968-969. Clarendon Press, Oxford, U.K.

JERRÅ, K. 2014. Investigating the phylogenetic relationships within Trema (Cannabaceae) and the species status of the New World taxa. Masters Thesis. Stockhoms Universitet, Sweden.

JSTOR GLoBAL PLANTS. (no date). Trema domingense. http://plants.jstor.org/. ITHAKA. Accessed 20 Feb 2018, 17 Aug 2018. Kalyanamoorthy, S., B.Q. Minh, T.K.F. Wong, A. von Haeseler, \& L.S. Jermin. 2017. ModelFinder: Fast model selection for accurate phylogenetic estimates. Nature, Meth. 14:587-589. doi:10.1038/NMETH.4285

КАTOH, K., K. MISAWA, K.-I. KUMA, \& T. MIYATA. 2002. MAFFT: A novel method for rapid multiple sequence alignment based on fast Fourier transform. Nucl. Acids Res. 30:3059-3066. doi:10.1093/nar/gkf436

Kearse, M., R. Moir, A. Wilson, S. Stones-Havas, M. Cheung, S. Sturrock, S. Buxton, A. Cooper, S. Markowitz, C. Duran, T. Thierer, B. Ashton, P. Mentiles, \& A. Drummond. 2012. Geneious Basic: An integrated and extendable desktop software platform for the organization and analysis of sequence data. Bioinformatics 28:1647-1649. doi:10.1093/bioinformatics/bts199

KRESS, W.J., I.C. LOPEZ, \& D.L. ERICKSON. 2012. Generating plant DNA barcodes for trees in long-term forest dynamics plots. In: W.J. Kress \& D.L. Erickson, eds. DNA barcodes: Methods and protocols. Meth. Molec. Biol. 858:441-458. doi:10.1007/978-1-61779-591-6_22

LASSER, T. 1971. Trema. In:T. Lassser, ed. Flora de Venezuela 3(1):18-23. Instituto Botanico, Caracas, Venezuela.

LegaARD, S. \& H. BalsLev. 2014. Trema. In C. Persson \& B. Ståhl, eds. Flora of Ecuador 91:66-71. University of Gothenburg, Sweden.

LEón-YÁnez, S. 1999. Ulmaceae. In: P.M. Jørgensen \& S. León-Yánez, eds. Catalog of the vascular plants of Ecuador. Missouri Botanical Garden, St. Louis, Missouri, U.S.A. Pp. 930. Trema: www.tropicos.org/Name/40016530?projectid=2. Accessed 19 Feb 2018.

LIOGIER, H.A. 1978. Appendices. In: M.D. Fuertes Loren, Catálogo de plantas colectadas por el Padre Fuertes, Museo del Hombre Dominicano, Academia de Ciencias de la República Dominicana, Santo Domingo, Pp. 143-220.

LIOGIER, H.A. 1996. Trema. La flora de la Española 8:426-432.

LITTLE, E.L. 1948. A collection of tree specimens from western Ecuador. Caribbean Forester 9(3):215-298.

LITTLE, E.L. \& R.G. Dixon. 1969. Arboles comunes de la provincia de Esmeraldas. Estudio de preinversión para el desarrollo forestal noroccidente. Informe Final. Roma, Italia, FAO, 4:53.

LOBECK, M. 2010. Functional ecology of secondary forests in Chiapas, Mexico. Masters Thesis, Wageningen University, Netherlands. http://citeseerx.ist.psu.edu/viewdoc/download?doi=10.1.1.707.4471\&rep=rep1\&type=pdf

LunDELL, C.L. 1960. Ulmaceae. Plantae Mayanae - 1. Notes on collections from the lowlands of Guatemala. Wrightia 2:50-51.

MAYTA, E., C.C. BerG, S.G. Beck, M. NeE, \& P.M. Jorgensen. 2014. Trema. In: P.M. Jørgensen, M.H. Nee, S.G. Beck, S. Arrázola, \& M. Saldia, eds. Catálogo de las plantas vasculares de Bolivia. Missouri Botanical Garden Press, St. Louis, Missouri, U.S.A. Pg. 482. Trema: www.tropicos.org/Name/40016530?projectid=13\&langid=66. Accessed 19 Feb 2018.

MilLeR, J.S. \& P.E. BerRy. 2005. Trema. In: J.A. Steyermark, P.E. Berry \& B.K. Holst, eds. Fl. Venez. Guayana 9:389-390. Missouri Botanical Garden Press, St. Louis, Missouri, U.S.A.

Molina Rosito, A. 1975. Trema. Enumeración de las plantas de Honduras. Ceiba 19(1):40.

MonRo, A.K. 2015. Urticaceae: Descripción de la familia y clave genérica. In: G. Davidse, M. Sousa Sánchez, S. Knapp, \& F. Chiang Cabrera, eds. Flora Mesoamericana 2(3):116-117. Urticaceae: www.tropicos.org/docs/meso/urticaceae.pdf. Accessed 19 Feb 2018.

Navarro Gomez, R. 2013. Trema micrantha. Distribución de las especies forestales del Perú. OSINFOR (Organismo de Supervisión de los Recursos Forestales y de Fauna Silvestre), Perú. Pg. 41. https://www.osinfor.gob.pe/publicaciones/ distribucion-de-las-especies-forestales-del-peru-2013/

NAtURHISTORISKA RiKSmUSEEt. (continuously updated). Herbarium Catalogue (S). Stockholm. http://herbarium.nrm.se/ search/species/. Accessed 17 Nov 2017.

NeE, M. 2015. Trema. In: G. Davidse, M. Sousa Sánchez, S. Knapp, \& F. Chiang Cabrera, eds. Flora Mesoamericana 2(3):176177. Missouri Botanical Garden, St. Louis, Missouri, U.S.A. Cannabaceae: www.tropicos.org/docs/meso/cannabaceae. pdf. Accessed 19 Feb 2018. 
Nepal, M.P, C. J. Ferguson, \& M.H. Mayfield. 2015. Breeding system and sex ratio variation in mulberries (Morus, Moraceae). J. Bot. Res. Inst. Texas 9:383-395.

Neubig, K., W. Whitten, J. Аввотt, S. Elliott, D. Soltis, \& P. Soltis. 2014. Variables affecting DNA preservation in archival plant specimens. In: W. Applequist \& L. Campbell, eds. DNA banking for the $21^{\text {st }}$ century: Proceedings of the U.S. Workshop on DNA Banking. Missouri Botanical Garden, St Louis, Missouri, U.S.A. Pp. 81-136.

NevLING, L.I. 1960. Trema. In: R.E. Woodson, R.W. Schery, \& collaborators, eds. Flora of Panama. Ann. Missouri Bot. Gard. 47:108-110.

NGUyen, L-T, H.A. SChmidt, A. von HaEseler, \& B.Q. MinH. 2015. IQ-TREE: A fast and effective stochastic algorithm for estimating maximum likelihood phylogenies. Molec. Biol. Evol. 32:268-274. doi:10.1093/molbev/msu300

Nicolson, D.H. 1990. Trema. Flora of Dominica, part 2: Dicotyledoneae. Smithsonian Institution Press, Washington, D.C., U.S.A.Pp. 218.

Pennington, T.D., C. Reynel, \& A. Daza. 2004. Trema. Illustrated guide to the trees of Peru. David Hung, publishers. Shelborne, U.K. Pg. 95-96.

PLANCHON, J.E. 1873. Sponia. In: A. de Candolle, ed. Prodromus systematis universalis regni vegetabilis 17:195-205.

RASBAND, W.S. 1997-2016. ImageJ 1.49v. U.S. National Institutes of Health, Bethesda, Maryland, U.S.A. http://imagej.nih. gov/ij

RiBAS, L.A. \& P.Y. KageYAmA. 2006. Sistema de cruzamento de Trema micrantha (L.) B. em fragmentos florestais. Sci. Forest. 72:29-37.

Seelanan, T., A. Schnabel, \& J.F. Wendel. 1997. Congruence and consensus in the cotton tribe (Malvaceae). Syst. Bot. 22:259-290. doi:10.2307/2419457

SeYmour, F.C. 1980. Ulmaceae. Check list of vascular plants of Nicaragua. Phytologia Mem. 1:120. (H.N. Moldenke \& A.L. Moldenke, ser. eds.): Plainfield, New Jersey, U.S.A.

StAFLEU, F.A. \& R.S. CowAN. 1976-1988. Taxonomic literature: A selective guide to botanical publications and collections with dates, commentaries and types. $2^{\text {nd }}$ edition. Bohn, Scheltema \& Holkema, Utrecht, Netherlands.

StAmATAKIS, A. 2014. RAxML Version 8: A tool for phylogenetic analysis and post-analysis of large phylogenies. Bioinformatics 30:1312-1313. doi:10.1093/bioinformatics/btu033

StandLey, P.C. 1931. Trema. Flora of the Lancetilla Valley Honduras. Publ. Field Mus. Nat. Hist., Bot. Ser. 10:163.

StANDLEy, P.C. 1933. Ulmaceae. The flora of Barro Colorado Island, Panama. Contr. Arnold Arbor. 5:55-56.

Standley, P.C. \& S.J. Record. 1936. Trema. The forests and flora of British Honduras. Publ. Field Mus. Nat. Hist., Bot. Ser. $12: 108$.

Standley, P.C. 1937. Trema. Flora of Costa Rica. Part 1. Publ. Field Mus. Nat. Hist., Bot. Ser. 12, Pp. 378.

Standley, P.C. \& J.A. SteYermark. 1946. Trema. Flora of Guatemala, part 4. Fieldiana: Bot. 24 (4):8-10.

St-Laurent, L., B.R. Baum, K. Akpagana, \& J.T. Arnason. 2000a. A numerical taxonomic study of Trema (Ulmaceae) from Togo, West Africa. Syst. Bot. 25:399-413.

St-Laurent, L., B.R. Baum, K. Akpagana, \& J.T. Arnason. 2000b. Leaf trichome morphology and density in West African Trema spp. (Ulmaceae: Celtidoideae). Canad. J. Bot. 78:34-39.

SwofFORD, D.L. 2002. PAUP*: Phylogenetic analysis using parsimony (*and other methods), Version 4.0 beta 10. Sinauer Associates, Sunderland, Massachusetts, U.S.A.

SYSTAT 13.1 fOR WInDOWs. 2009. Systat Software, Inc. San Jose, California, U.S.A.

Taberlet, P., L. Gielly, G. PAutou, \& J. Bouvet. 1991. Universal primers for amplification of three non-coding regions of chloroplast DNA. PI. Molec. Biol. 17:1105-1109. doi:10.1007/BF00037152

The PLANT LIST. (2013). Version 1.1. Published on the internet. www.theplantlist.org/. Accessed 20 Feb 2018.

TodzIA, C.A. 2001. Trema. In: W.D. Stevens, C. Ulloa U., A. Pool, \& O.M. Montiel, eds. Flora of Nicaragua. Monogr. Syst. Bot. Missouri Bot. Gard. 85(3):2478.

ToRRES, R.B. 1996. Biologia da reprodução de Trema micrantha (L.) Blume (Ulmaceae). Tese (doutorado). Universidade Estadual de Campinas, Instituto de Biologia, Campinas, SP, Brasil. http://repositorio.unicamp.br/jspui/handle/ REPOSIP/315042

Trifinopoulos, J., L.-T. Nguyen, A. von Haeseler, \& B.Q. Minh. 2016. W-IQ-TREE: A fast online phylogenetic tool for maximum likelihood analysis. Nucl. Acids Res. 44:W232-W235. doi:10.1093/nar/gkw256

TRoPICOs. 2018. Tropicos.org. Missouri Botanical Garden. www.tropicos.org

Tropicos. 2018a. Sponia integerrima. www.tropicos.org/Name/33300162. Accessed 15 Feb 2018.

TROPICOS. 2018b. Trema integerrima. www.tropicos.org/Name/33300167. Accessed 15 Feb 2018. 
TROPICOS. 2018c. Trema laxiflora. www.tropicos.org/Name/33300219. Accessed 15 Feb 2018.

TROPICOS 2018d. Trema domingense. www.tropicos.org/Name/100368643. Accessed 7 Mar 2018.

Ulloa Ulloa, C., P. Acevedo-Rodríguez, S.G. Beck, M. J. Belgrano, R. Bernal, P.E. Berry, L. Brako, M. Celis, G. Davidse, S.R. Gradstein, O. Hokche, B. León, S. León-Yánez, R.E. Magill, D.A. Neill, M.H. Nee, P.H. Raven, H. Stimmel, M.T. Strong, J.L. Villaseñor Ríos, J.L. ZARUCCHI, F.O. ZULOAGA, \& P.M. JøRGENSEN. 2017. An integrated assessment of vascular plants species of the Americas. Science 358:1614-1617, f. 1-4. doi:10.1126/science.aao0398

URBAN, I. 1900. Duss. Flor. Ant. franc. Bibliographia Indiae occidentalis botanica. Symb. Antill. (Urban) 1:39-41.

URBAN, I. 1909. Ulmaceae. Incrementa florae jamaicensis. Symb. Antill. (Urban) 6(1):99.

URBAN, I. 1912. Ulmaceae. Nova genera et species V. Symb. Antill. (Urban) 7(2):191-192.

URBAN, I. 1920. Trema. Flora Domingensis. Symb. Antill. (Urban) 8:164-165.

VARGAS, W.G. \& A. IDÁRRAGA. 2011. Trema. In: A. Idárraga Piedrahíta, R. Del Carmen Ortiz, R. Callejas Posado, \& M. Merello, eds. Flora de Antioquia, Catálogo de las Plantas Vasculares 2:391. Missouri Botanical Garden, St. Louis, Missouri, U.S.A.

VILLASEÑOR, J.L. 2016. Checklist of the native vascular plans of Mexico. Revista Mex. Biodivers. 87:559-902. doi:10.1016/j. rmb.2016.06.017

Weddell, H.A. 1854. Margarocarpus to Pouzolzia. Revue de la famille des Urticées. Ann. Sci. Nat., Bot., sér. 4, 1:203-206.

Weddell, H.A. 1856 [1857]. Pouzolsia. Monographie de la famille des Urticées. Arch. Mus. Hist. Nat. 9:389-415.

WIGHT, R. 1853. Icones plantarum Indiae Orientalis, vol. 6. (242 plates).

Wilmot-Dear, C.M., I. Frils, \& A.K. Monro. 2015. Pouzolzia. In: G. Davidse, M. Sousa Sánchez, S. Knapp, \& F. Chiang Cabrera. Flora Mesoamericana 2(3):161-165. Urticaceae. www.tropicos.org/docs/meso/urticaceae.pdf. Accessed 19 Feb 2018.

Xu, D.H., J. ABe, M. Sakal, A. Kanazawa, \& Y. Shimamoto. 2000. Sequence variation of non-coding regions of chloroplast DNA of soybean and related wild species and its implications for the evolution of different chloroplast haplotypes. Theor. Appl. Genet. 101:724-732. doi:10.1007/s001220051537

Yang, M.-Q., R. van Velzen, F.T. Bakker, A. SAttaRian, D.-Z. LI, \& T.-S. Yı. 2013. Molecular phylogenetics and character evolution of Cannabaceae. Taxon 62:473-485. www.jstor.org/stable/taxon.62.3.473

Yesson, C., S. J. Russell, T. Parrish, J.W. Dalling, \& N.C. Garwood. 2004. Phylogenetic Framework for Trema (Celtidaceae). PI. Syst. Evol. 248:85-109. doi:10.1007/s00606-004-0186-3

ZANONI, T.A. \& M.M. MEJíA P. 1989. Notas sobre la Flora de la Isla Espanola. III. Moscosoa 5:85-115.

ZARUCCHI, J.L. \& C.A. TodZIA. 1993. Ulmaceae. In: L. Brako \& J.L. Zarucchi, eds. Catalogue of the flowering plants and gymnosperms of Peru. Monogr. Syst. Bot. Missouri Bot. Gard. 45:1152-1153. www.tropicos.org/Name/40016530?projectid=5. Accessed 19 Feb 2018. 